\title{
LA HISTORIOGRAFÍA ANTE LA CORRESPONDENCIA APÓCRIFA ENTRE LOS JUDÍOS DE ESPAÑA Y LOS DE CONSTANTINOPLA: UNA REVISIÓN CRÍTICA
}

\section{The Apocryphal Correspondence between the Jews of Spain and those of Constantinople in Historiography: A Critical Review}

\author{
Fernando BRAVO LÓPEZ \\ Investigador sin vinculación \\ Correo-e: fernandobravolopez@yahoo.es
}

RESUMEN: Durante unos cuatrocientos años, la correspondencia entre los judíos de España y los de Constantinopla ha ocupado un importante lugar dentro de la tradición antijudía europea. Los autores antijudíos la han usado durante todo ese tiempo como prueba de la existencia de un plan judío para apoderarse de la sociedad cristiana desde dentro. Desde principios del siglo xix la correspondencia ha ocupado también un lugar importante dentro de la historiografía. Este artículo se centra en esta cuestión, realizando un repaso al tratamiento que la correspondencia ha recibido por parte de la historiografía, mostrando cómo se impuso el criterio de que las cartas eran apócrifas, y cómo empezaron a surgir preguntas en torno a su origen y propósito. Se mostrarán las respuestas que se han dado a esas preguntas, y que todavía queda mucho por saber acerca de estos importantes documentos.

Palabras clave: tradición antijudía; judíos en España; conversos; conspiración; estatutos de limpieza de sangre; historiografía.

ABSTRACT: The correspondence between the Jews of Spain and those of Constantinople has occupied an important place within the European

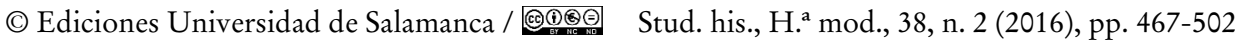


anti-Jewish tradition for around four hundred years. Anti-Jewish authors have used it for centuries as a proof of the existence of a Jewish conspiracy designed to take control of the Christian society from the inside. Since the Nineteenth Century, the correspondence has also occupied an important place in historiography. This article focuses in this issue, reviewing the way the correspondence has been treated in historiography. It will show how the view that the letters were a fake prevailed, and how questions about its real origin and motivation emerged. Finally, we will show the answers that have been proposed to these questions, and that there are still many things unknown about those important documents.

Key words: Anti-Jewish Tradition; Jews in Spain; Conversos; Conspiracy; Purity of Blood Statutes; Historiography.

\section{INTRODUCCIÓN}

Dentro de la tradición antijudía europea existe la leyenda de que, al poco de decretarse la expulsión de los judíos de España, estos escribieron a los judíos de Constantinopla pidiendo consejo sobre lo que debían hacer: ¿convertirse o marchar? Los judíos de Constantinopla respondieron al requerimiento recomendando a los de España que se convirtieran, y que, una vez convertidos, hicieran a sus hijos mercaderes para apoderarse de las haciendas de los cristianos, médicos para acabar con sus vidas, clérigos para destruir su Iglesia, y que, en definitiva, ocuparan toda la clase de oficios que permitieran dominar a los cristianos y vengarse así de ellos. La leyenda se ha apoyado durante siglos en la existencia de las propias cartas -la pregunta de los judíos de España y la respuesta de los de Constantinopla-, las cuales se han presentado como auténticas, y así han circulado por buena parte de Europa, reproducidas una y otra vez en multitud de obras que pretendían mostrar que los judíos, aun convertidos, eran una amenaza constante para los cristianos. Y más aún: que los convertidos resultaban todavía más peligrosos que los «públicos», porque la conversión -que conllevaba la igualdad jurídica- les permitía dominar a los cristianos de manera más efectiva.

La importancia de la correspondencia entre los judíos de España y los de Constantinopla difícilmente puede ser minimizada. Considerada a menudo como precedente claro de Los protocolos de los sabios de Sión ${ }^{1}$, durante unos cuatrocientos

1. Vid., por ejemplo, Álvarez Chillida, G.: El antisemitismo en España: la imagen del judio, 1812-2002. Madrid, 2002, p. 46. Agradezco al profesor Álvarez Chillida sus comentarios a este artículo.

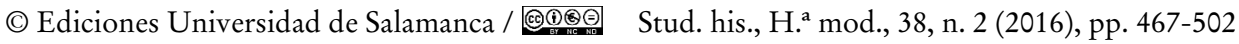



Y LOS DE CONSTANTINOPLA: UNA REVISIÓN CRÍTICA

años ha servido para transmitir la idea de la existencia de una verdadera conspiración judía para infiltrarse en la sociedad cristiana y destruirla desde dentro. Desde la España del siglo XVII, pasando por la Francia de finales del xix y la Alemania nazi, hasta nuestros días, las cartas se han convertido en un elemento omnipresente en la tradición antijudía europea occidental.

Sin embargo, aún sabemos poco de ellas. Desde finales del siglo xix no se ha vuelto a realizar un estudio detallado de este tema; y un aspecto fundamental, como es el origen mismo de las cartas, permanece aún irresuelto. Aunque, como veremos, se han manejado diversas hipótesis, estamos lejos de poder determinar, más allá de cualquier duda razonable, cuál fue el origen exacto de las cartas. Este artículo, lo adelantamos, no resolverá el misterio. Lo que pretende únicamente es establecer de manera exhaustiva qué sabemos, y qué no, acerca de la correspondencia entre los judíos de España y los de Constantinopla.

Una de las cosas que sabemos con seguridad acerca de las cartas es que durante un tiempo circularon en manuscrito por toda España -e incluso fuera de ella-, y que aparecieron por primera vez impresas en la obra de Julián de Medrano, La silva curiosa, publicada en París en 1583. Si primero fueron los manuscritos y después el texto impreso, o al revés, es precisamente lo problemático. Después, durante el siglo XVII, las cartas circularon impresas en numerosas obras de diferente carácter, desde la Sylva responsorum iuris de Ignacio del Villar Maldonado, pasando por el Discurso contra los judios de Vicente da Costa Matos, el Centinela contra judios de Francisco de Torrejoncillo y el Tractatus de officialibus reipublicae de Antonio Fernández de Otero. También encontramos una breve referencia, sacada de Ignacio del Villar, en la Execración contra los judios de Quevedo, quien, aunque dudaba de la veracidad de los documentos, creía que eran un fiel reflejo de la conducta que los conversos habían tenido. De ahí pasaron al siglo XviI, apareciendo en las obras de Félix Alamín, Antonio Contreras y Sebastián de Acuña².

A mediados del siglo XVII, las cartas tuvieron la fortuna -por lo que concierne a su difusión y pervivencia posterior- de aparecer en la obra del abate Bouis, La

2. Villar Maldonado, I.: Sylva responsorum iuris. Madrid, 1614, fols. 132v.-133r; Costa Matos, V.: Breve discurso contra a heretica perfidia do judaismo. Lisboa, 1623, f. 55v (traducido al castellano por Diego Gavilán Vela y publicado en Salamanca en 1631); Torrejoncillo, F.: Centinela contra judios. Madrid, 1676 [1. ${ }^{a}$ ed. 1674], pp. 86-87; Alamín, F.: Impugnación contra el Talmud de los judios, al Coran de Maboma, y contra los hereges. Madrid, 1727, p. 57; Contreras, A.: Mayor fiscal contra judios. Madrid, 1736, pp. 130-132; Acuña, S.: Dissertaciones sobre el órden, que los médicos deben observar en las juntas. Madrid, 1746, pp. 49-50; Fernández de Otero, A.: Tractatus de officialibus reipublicae. Ginebra, 1750 [1. ${ }^{\mathrm{a}} \mathrm{ed}$. Lyon, 1682], pp. 11-12.; Quevedo, F.: Execración contra los judios. Edición de Fernando Cabo y Santiago Fernández, Barcelona, 1996, p. 11.

(C) Ediciones Universidad de Salamanca / ®@ Stud. his., H. ${ }^{a}$ mod., 38, n. 2 (2016), pp. 467-502 
royalle couronne des roys d'Arles, donde además sufrieron una transformación importante. La primera de las cartas, la supuestamente dirigida a los judíos de Constantinopla por los de España, pasó a llamarse «Carta de los judíos de Arlés a los de Constantinopla»; y de estar escrita en castellano, pasó a estarlo en provenzal. La segunda de las cartas, en consecuencia, pasó a ser la «Carta de los judíos de Constantinopla a los judíos de Arlés», aunque no dejó de estar escrita en castellano ${ }^{3}$. A finales del siglo xix, una publicación de provincias, la Armana Prouvençau, las rescató del aparente olvido en el que habían permanecido, asegurando que habían sido encontradas en el archivo de Arlés, cuando, en realidad, habían sido copiadas de la obra de Bouis. Al poco, se hizo eco del «descubrimiento» la Revue des Langues Romanes, y, tras ella, Arsène Damesteter en un artículo de la Revue des Études Juives ${ }^{4}$.

Paradójicamente, fue la publicación de las cartas en la Revue des Études Juives -publicación que siempre ha jugado un importante papel en la lucha contra los prejuicios antijudíos- lo que permitió que los círculos antisemitas franceses de finales del XIX conocieran las cartas y las volvieran a poner en circulación. Efectivamente, de la publicación en la Revue se hizo eco el abate Chabauty en su famosa obra Les juifs, nos maîtres! Tras ello, las cartas aparecieron en un buen número de publicaciones antisemitas, desde La France juive de Édouard Drumont, pasando por Le mystère du sang de Henry Desportes, La franc-maçonnerie, synagogue de Satan de Léon Meurin, las obras de Copin-Abancelli, de Flavien Brenier, de Roger Lambelin, etc. ${ }^{5}$.

Las cartas pudieron difundirse a otros países gracias a la importancia que adquirieron dentro del arsenal acusatorio del antisemitismo francés. De él pasaron al resto de países donde el antisemitismo ganaba fuerza. Las encontramos, por ejemplo, en alguna de las ediciones de los Protocolos de los Sabios de Sión, expuestas como precedente, y como demostración de la realidad del plan secreto judío para

3. Bouis, J.: La royalle couronne des roys d'Arles. Aviñón, 1641, pp. 475-477.

4. «La letro di jusiou d'Arle», Armana Prouvençau, 1880, pp. 61-62; Roque-Ferrier, A.: «Bibliographie. Armana prouvençau», Revue des Langues Romanes, 3ème série (tome II), 1879, pp. 301-304; Darmesteter, A.: «Lettres des juifs d'Arles et de Constantinople», Revue des Etudes Juives, 1, 1880, pp. 119-123.

5. Chabauty, E.-A.: Les Juifs, nos maîtres! París, 1882, pp. 4-19; Drumont, É.: La France Juive. 2 vols., París, 1886, vol. 1, pp. 216-217; Desportes, H.: Le mystère du sang chez les juifs de tous les temps, París, 1890, pp. 336-337; Meurin, L.: La franc-maçonnerie, synagogue de Satan, París, 1893, pp. 207-209; Copin-Albancelli, P.: La conjuration juive contre le monde chrétien, París, 1909, pp. 360-366; Brenier, F.: Les juifs et le Talmud. París, 1913, p. 44, nota; LAMBelin, R.: Le péril juif. París, 1924, pp. 14-16.

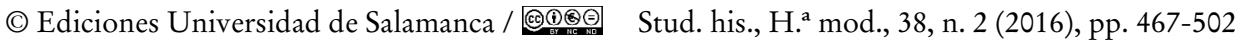


infiltrarse en la sociedad cristiana y apoderarse de ella ${ }^{6}$ También las encontramos, obviamente, en el antisemitismo alemán. Aparecieron, por ejemplo, en 1934, en una publicación perteneciente al grupo editorial de Julius Streicher ${ }^{7}$, la Salud del pueblo alemán a través de la sangre y el suelo, donde se publicó un artículo dedicado a los médicos judíos, a su supuesta predisposición a matar a los pacientes gentiles: «El judío», decía, «nunca ha tenido el deseo de curar a los no judíos. Su objetivo es arruinar su salud». Y para probarlo, Karl Holz, autor del texto y uno de los más cercanos colaboradores de Streicher, no encontraba nada mejor que remitirse a una llamada «carta judía de Toledo, un documento de 1489» que, al parecer, mostraba a las claras que, efectivamente, los judíos, cuando eran médicos, no curaban a los gentiles, sino que hacían todo lo posible por acabar con ellos. Holz resumía brevemente la historia de la carta: «en ese año [1489], a los judíos del norte de Francia se les dio la opción de emigrar o de ser bautizados. El rabino de Arlés pidió consejo al líder supremo secreto de los judíos en Constantinopla», quien respondió dando los consabidos consejos a sus correligionarios de Francia. El autor daba muestras de una evidente falta de cultura geográfica -Arlés, como se sabe, está en el Sur de Francia, y no en el norte-, y no se entendía muy bien a cuento de qué, una carta de Constantinopla en respuesta a otra proveniente de Arlés, se llamaba «carta judía de Toledo». Pero, a pesar de esa evidente falta de congruencia, se esgrimían las cartas como un documento auténtico, un testimonio fidedigno del carácter maléfico del pueblo judío ${ }^{8}$. Poco después, la correspondencia aparecería también en la obra más importante de Gregor Schwartz-Bostunitsch, uno de los miles de rusos de origen alemán que buscaron refugio en Alemania tras la Revolución comunista de 1917, miembro del partido nazi y uno de los principales difusores del contenido de Los protocolos de los sabios de Sión ${ }^{9}$. Y, evidentemente, las cartas siguieron estando muy presentes en el antisemitismo español hasta bien entrado el siglo $\mathrm{xx}^{10}$.

6. The protocols of the meetings of the learned elders of Zion. With a preface and explanatory notes, translated from the Russian text by Victor E. Marsden, s. 1., 1934, pp. 98-99.

7. Julius Streicher (1885-1946) fue uno de los más importantes propagandistas del régimen nazi, y sin duda el más obscenamente antisemita. Su publicación más importante, Der Stürmer, fue famosa por su furibundo antisemitismo. Streicher fue juzgado en Nuremberg y condenado a la horca. Sobre él, Vid. ByTwerk, R. L.: Julius Streicher. Nueva York, 2001.

8. Holz, K.: "The Jew and Healing», en German Propaganda Archive, traducción de Randall Bytwerk, accesible en: http://www.calvin.edu/academic/cas/gpa/dvg34-23.htm [fecha de consulta: 3/11/2015]. El artículo original fue publicado como «Jude und Heilkunde», Deutsche Volksgesundheit aus Blut und Boden!, 2, n. ${ }^{\circ} 23,1$ de diciembre de 1934, pp. 1-2.

9. Schwartz-Bostunitsch, G.: Jüdischer Imperialismus. Leipzig, 1937, pp. 182-183. Sobre este personaje Vid. CoHn, N.: El mito de la conspiración judía mundial. Madrid, 1995, p. 184.

10. Vid. Álvarez Chillida: op. cit., pp. 143, 290, 459. 
Así, ya sea en su versión española, ya en su versión francesa, la correspondencia entre los judíos de España y los de Constantinopla ha continuado siendo reproducida en infinidad de obras antisemitas, y todavía se puede encontrar en diversos sitios de Internet de ese carácter. Sorprendentemente, todavía en el año 2000 apareció en un artículo publicado en $A B C$ cuyo objetivo no era otro que legitimar el establecimiento del Santo Oficio por los Reyes Católicos, dadas las intenciones conspirativas de los conversos ${ }^{11}$.

Debido a la importancia que la correspondencia ha tenido dentro de la tradición antijudía europea, ha sido objeto del interés de la historiografía dedicada al estudio del pasado judío en la Península y en Francia, así como al estudio de la tradición antijudía europea. Dentro de esa historiografía, la autenticidad de las cartas empezó a ser cuestionada desde principios del siglo xix, algo que los antisemitas, desde luego, prefirieron ignorar o considerar parte de la conspiración para ocultar la realidad del dominio judío.

A lo largo de las siguientes páginas haremos una revisión del tratamiento que han recibido estas cartas en la historiografía. Veremos cómo han pasado de ser consideradas un testimonio único del carácter del pueblo judío, a ser valoradas como un producto de la ideología cristiano-vieja surgida a partir de las conversiones masivas de finales del siglo xIv. Mostraremos, asimismo, las principales tendencias que han tratado de explicar las razones por las que esta correspondencia se fabricó, y quién estuvo detrás de ello. Veremos, en este sentido, cómo se han considerado una creación destinada a legitimar los estatutos de limpieza de sangre, o, por el contrario, como una manifestación del ingenio satírico de algún literato. Se verá, finalmente, que estamos aún lejos de encontrar una respuesta satisfactoria a la mayoría de las cuestiones que se han planteado a lo largo del tiempo.

Nos centraremos en el periodo posterior a 1880 , pues fue a partir de entonces cuando las cartas adquirieron su verdadera importancia internacional. Sin embargo, señalaremos que, ya desde principios del siglo XIX, las cartas habían despertado la atención de los historiadores. De hecho, fue Juan Antonio Llorente el primer historiador en poner en duda la autenticidad de la correspondencia, señalando, una vez expuesto el contenido de la misma, que «yo no salgo garante de la verdad de esta narración, porque las cartas se me figuran fingidas por alguno de los muchos que tomaron medios parecidos a éste para perseguir a los cristianos de familias hebreas» ${ }^{12}$.

11. Barrios, M.: «Álbum de recuerdos», ABC. Edición de Sevilla, 15 de enero de 2000.

12. Llorente, J. A.: Anales de la Inquisición española. 2 vols., Madrid, 1812-1813, vol. 1, pp. 197-199.

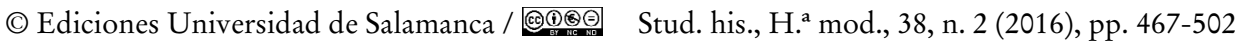


Tras él, varios historiadores españoles se detuvieron en este tema, aunque una parte de ellos siguió considerando que la correspondencia era auténtica. Fue el caso de José María Montero de Espinosa, Matías Sangrador Vítores, y del propio José Amador de los Ríos, quien, primero en 1846 en una serie de artículos, y después en 1848 , se resistió a aceptar la falsedad de los documentos ${ }^{13}$. A pesar de ello, el criterio de que las cartas eran una fabricación espuria se fue imponiendo poco a poco, y el problema principal pasó a ser la atribución de su autoría.

Aunque desde los años de José Antonio Llorente se había señalado una vinculación con el arzobispo de Toledo, Juan Martínez Silíceo, el primer historiador que le atribuyó la autoría de las cartas fue Adolfo de Castro, quien aseguraba que las hizo públicas como si las hubiera encontrado en el archivo de la catedral, y las utilizó ante Roma para obtener la confirmación del estatuto de limpieza que trataba de imponer en su iglesia. Castro no hacía más que seguir lo que algunos manuscritos, como el del Libro verde de Aragón, afirmaban acerca del hallazgo de Silíceo, solo que, sin aportar prueba alguna, iba más allá para acusar al propio arzobispo de la fabricación de los documentos ${ }^{14}$. Ningún otro autor, hasta finales del siglo XIX, se detuvo en esta cuestión.

A grandes rasgos, así estaban las cosas cuando la Armana Prouvençau, una casi desconocida publicación francesa de provincias, publicó las cartas como si el autor del artículo las hubiera encontrado en el archivo de la ciudad de Arlés.

\section{El debate en la REVUE DES ÉTUDES JUIVES}

Sin duda, el debate más importante acerca del origen y objetivo de la correspondencia entre los judíos de España y los de Constantinopla tuvo lugar a finales del xix en el seno de la Revue des Études Juives. Como señalamos en la introducción, en 1880 Arsène Damesteter se hizo eco en sus páginas de la publicación en la Armana Prouvençau de ambas cartas, copiadas de la obra de Bouis, pero asegurando que se habían encontrado en los archivos de Arlés. Damesteter señalaba la procedencia real, evidenciando la falsedad del hallazgo archivístico. A la

13. Montero de Espinosa, J. M.: Relación histórica de la judería de Sevilla. Sevilla, 1820, pp. 20-21; Sangrador Vítores, M.: Historia de la muy noble y leal ciudad de Valladolid. 2 vols., Valladolid, 1851-1854, vol. 2, pp. 80-81. José Amador de los Ríos se resistió a aceptar la falsedad de las cartas, hasta que en 1875 afirmó rotundamente que eran una falsificación evidente. Vid. Amador DE los Ríos, J.: «De los judíos de España. Artículo X y último», Revista Literaria de El Español, 38, 1846, pp. 5-9; AMADOR DE LOS Ríos, J.: Estudios históricos, políticos y literarios sobre los judios de España. Madrid, 1848, pp. 203-205; Amador DE los Ríos, J.: Historia social, política y religiosa de los judíos de España y Portugal. 3 vols., Madrid, 1875, vol. 1, p. 503.

14. Castro, A.: Historia de los judios en España. Cádiz, 1847, pp. 137-142.

(C) Ediciones Universidad de Salamanca / ®@ Stud. his., H. ${ }^{a}$ mod., 38, n. 2 (2016), pp. 467-502 
vez, consideraba que «la respuesta de Constantinopla es sin duda original»-en el sentido de que era ciertamente particular y curiosa-, seguramente la obra de un «ingenioso falsificador», cuyo trabajo recordaba en ocasiones a ciertos pasajes de Molière. Damesteter se preguntaba también por el origen de las cartas, descartando que Bouis pudiera haber escrito la que aparecía en español, y suponiendo que la habría copiado de un original castellano del siglo Xv o xvI, posterior con toda seguridad a 1489 -la fecha que, según Bouis, llevaban las cartas-. ¿Serían la obra de un falsificador cristiano deseoso de excitar el odio contra los judíos?, se preguntaba Damesteter. Finalmente, también realizaba una reflexión en torno al origen del nombre «Chamorre» que firmaba la carta de los judíos de Arlés, indicando que quizás provenía de «Chamor», que en hebreo significa «asno» ${ }^{15}$.

Al pequeño artículo de Damesteter contestó inmediatamente el gran hispanista francés Alfred Morel-Fatio, quien estaba totalmente familiarizado con las cartas. Estas, decía el autor, eran bien conocidas y habían sido publicadas en diversas ocasiones. Eran una «falsificación española del siglo XVI, cuyo objetivo (...) habría sido agravar, si fuera posible, las medidas de rigor tomadas contra los nuevos conversos (...) después de la expulsión de 1492». Morel-Fatio recordaba a Adolfo de Castro, al que consideraba el primero en haber tratado acerca de ellas, señalando que, sin dar pruebas, las atribuía al cardenal Juan Martínez Silíceo. En cualquier caso, recordaba que la primera vez que las cartas fueron llevadas a la imprenta fue en la obra de Julián de Medrano, La silva curiosa, impresa en París en 1583. Seguidamente, comparaba las que aparecían en la obra de Bouis con las que aparecían en la de Medrano, evidenciando que el primero, o había copiado al segundo, o había tomado las cartas de un manuscrito español; pero que, en definitiva, no tenían ninguna relación con la historia de los judíos de Provenza -algo que, como se verá, no era del todo exacto-. Apuntaba igualmente que existían diferentes manuscritos. De hecho, pensaba que había tantas copias manuscritas que «no hay una gran biblioteca de España que no posea algún ejemplar en las colecciones de misceláneas literarias o históricas». Él, por su parte, conocía 3 copias conservadas en la Biblioteca Nacional de Francia -espagnol 354, espagnol 372 y Baluze 238-.

Finalmente, Morel-Fatio pensaba que eran quizás obra de algún literato español de la segunda mitad del XVI, inspirado por las disputas sobre el estatuto de limpieza de sangre del arzobispo Silíceo, pero no creía que el autor fuera el propio arzobispo, ni que hubieran sido escritas como un arma contra los «judaizantes». La inclusión de las cartas en tantas colecciones misceláneas de escritos satíricos,

\section{Darmesteter: op. cit.}

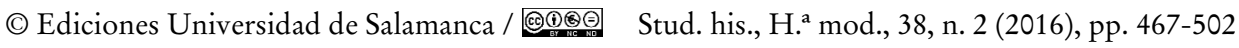


humorísticos y poéticos, sugería que fueron creadas como textos de divertimento. Finalmente, en cuanto al nombre «Chamorra» de la primera carta, señalaba que no solo remitía a «asno», sino que en castellano «chamorro» significaba «animal de cabeza esquilada» ${ }^{16}$.

Habría que esperar a 1887 para que se produjera una nueva aportación al tema, de la mano de Isidore Loeb. Entremedias, había visto la luz el Libro verde de Aragón, editado por Rodrigo Amador de los Ríos, el cual contenía las cartas, además de una serie de textos colocados antes y después de ellas. Se trataba del texto referente a las razones que el rey Fernando el Católico tuvo para expulsar a los judíos, un pequeño texto sobre cómo el arzobispo Silíceo encontró las cartas en el archivo de la catedral de Toledo, y, tras reproducir las propias cartas, un texto acerca de cómo estas fueron enviadas al papa como prueba de la necesidad de introducir el estatuto de limpieza de sangre de la catedral Primada ${ }^{17}$. Añadía Rodrigo Amador de los Ríos, en su estudio inicial, una observación que resultaba especialmente interesante: las cartas, así como los demás documentos que seguían al folio 74 del Libro, habían sido añadidos después de 1575; mucho después, por tanto, de la redacción del núcleo central del documento, compuesto supuestamente hacia $1507^{18}$.

Loeb, por su parte, en su aportación aparecida en la Revue des Études Juives, empezaba recordando los trabajos de Damesteter y Morel-Fatio, y seguidamente reproducía las cartas, tal y como aparecían en la obra de Medrano, en su edición de 1583, ya que Morel-Fatio solo había podido consultar la de 1608. Señalaba también que aparecían en la obra de Francisco de Torrejoncillo, añadiendo -no sabemos por qué motivo- que este las situaba en la época de las persecuciones visigodas. Loeb afirmaba también que, mientras Torrejoncillo otorgaba gran autoridad a las cartas, otros autores, como Medrano, no parecían haberlas tomado en serio. Con este comentario Loeb evidenciaba que no consideraba a Medrano el autor de las cartas, sino un mero transmisor, como Torrejoncillo y los demás. Por otro lado, con respecto a la aparición de las cartas en la obra de Bouis, Loeb se mostraba de acuerdo con Morel-Fatio en que no tenía sentido vincularlas con la historia de los judíos de Provenza. En cuanto a la autoría de Silíceo atribuida por Castro, Loeb consideraba que no estaba probada.

16. Morel-Fatio, A.: «Les lettres des Juifs d'Arles et de Constantinople: lettre a M. Arsène Darmesteter», Revue des Études Juives, 1, 1880, pp. 301-304.

17. Amador de los Ríos, R.: «El Libro verde de Aragón», Revista de España, 106, 1885, pp. 249-288, 567-603.

18. Idem, 105, 1885, pp. 547-578.

(C) Ediciones Universidad de Salamanca / ®@ Stud. his., H. ${ }^{a}$ mod., 38, n. 2 (2016), pp. 467-502 
Lo más importante de la aportación de Loeb era su detallada demostración de la falsedad de las cartas. Aunque, durante los años anteriores, la mayor parte de los historiadores habían asumido su falsedad, no habían hecho otra cosa que enunciarla, sin aportar ninguna prueba o argumento para sostener tal creencia, debido, seguramente, a que les parecía algo tan evidente que no merecía mayor discusión. Sin embargo, hacia 1887 ya estaba claro que en los círculos antisemitas franceses las cartas se tomaban en serio, y empezaban a circular como prueba evidente de la malignidad judía. Seguramente por esta razón, Loeb se tomó la molestia de probar su falsedad más allá de toda duda.

Para ello, en primer lugar, mostró que las cartas pretendían datar de la época inmediatamente anterior a la expulsión, pero, en realidad, eso no tenía mucho sentido, porque, según Loeb, la comunidad judía de Constantinopla solo empezó a ganar importancia después, y no antes, de la expulsión, gracias especialmente a la llegada de judíos españoles. Por ello, no habría sido lógico que los judíos españoles buscaran consejo en Constantinopla.

Loeb también dedicaba algún espacio a la cuestión de las firmas, que consideraba evidentemente falsas. Chamorra o Chamorro era claramente una expresión injuriosa, por lo que resultaba imposible que un judío firmara así. Era evidente igualmente que nunca había existido un príncipe, ni un jefe, de los judíos de España. De la misma manera, señalaba que el título de «rey de España» que se utilizaba al principio de la primera carta, solo podía ser posterior a 1492, por tanto posterior y no anterior a la expulsión. Y finalmente, el «Usussf» -en realidad «Ussusff», en la edición de Medrano de 1583- que firmaba la carta de Constantinopla, no tenía sentido, pues se sabe que, en la época, el gran rabino de Constantinopla era Moisés Capsali. Tampoco tenía ningún sentido la mención a los grandes sátrapas. Para finalizar, Loeb trascribía una carta real en hebreo, con su traducción al francés, para que el lector pudiera comprobar cómo sería una carta real de los judíos de la época.

En definitiva, según Loeb, todo se explicaba si consideramos que, en realidad, fue un cristiano el autor de las cartas, un cristiano del siglo xvi que las escribió «veinte o treinta años al menos después de la expulsión de los judíos de España» ${ }^{19}$.

La última palabra en el debate de la Revue des Études Juives la tuvo, dos años después, Heinrich Graetz, el gran historiador del judaísmo. Para esa fecha, el autor alemán ya había podido consultar la edición del Libro verde de Aragón realizada por Rodrigo Amador de los Ríos, y esa fuente parecía darle la clave para entender

19. Lоeв, I.: «La correspondance des Juifs d'Espagne», Revue des Études Juives, 15, 1887, pp. 262-276.

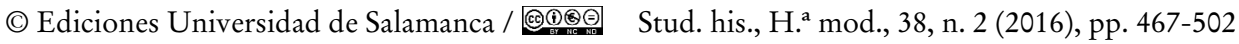


el origen de las cartas y el objetivo por el que fueron fabricadas. Graetz señalaba que, efectivamente, las cartas se encontraban en el Libro verde, realizado en 1507 por el secretario de la Inquisición Juan de «Anchisas» (i.e. Anchías). Y en esa obra las cartas iban precedidas de unas líneas en donde, según afirmaba Graetz, se explicaba que fueron hechas para que el papa Paulo III confirmara el estatuto de limpieza de sangre que el arzobispo Silíceo había introducido en la catedral de Toledo. Graetz, en esto, iba más allá de lo que el texto que citaba decía realmente. Como se recordará, únicamente decía que las cartas fueron utilizadas por el arzobispo para convencer al papa de la necesidad del estatuto, no que aquel las hubiera fabricado. En cualquier caso, Graetz aceptaba y defendía que esos eran ciertamente el origen y el objetivo de las cartas; y, como Castro, consideraba que el autor fue Silíceo mismo.

Graetz señalaba también, siguiendo un texto de Fidel Fita, que Silíceo, en su defensa del estatuto de limpieza, se hacía eco del mito del asesinato ritual del niño de La Guardia, y situaba el fantástico asesinato en un momento cercano en el tiempo, con la intención de dar a entender que la promulgación del estatuto y el asesinato ritual tenían una relación de causa-efecto. Sin embargo, señalaba Graetz, el proceso contra los supuestos perpetradores del asesinato tuvo lugar en 1490-91. La mala fe de Silíceo en este caso demostraría su capacidad de manipulación, y vendría a aportar un indicio sobre su posible autoría de las cartas.

Por otro lado, la utilización de la firma de «Chamorra» o «Chamorro» demostraba que las cartas tenían un objetivo práctico, político, y no de entretenimiento, como había sostenido Morel-Fatio. El apellido Chamorro aparecía en el Libro verde. Pertenecía a una de las principales familias conversas de Zaragoza, la cual ocupaba un lugar importante dentro de la corte real. Precisamente por eso, el autor de las cartas lo habría elegido para firmar la carta de los judíos de España. Así le daba credibilidad, y, a la vez, desacreditaba a una importante familia noble de origen converso.

En cuanto a la relación entre las cartas españolas y las cartas de la obra de Bouis, Graetz decía que eran copia las segundas de las primeras, y que las circunstancias que reflejaban las cartas no se podían aplicar a Arlés: ningún rey de Francia obligó a los judíos de Arlés a convertirse, decía Graetz. Además, Bouis decía que en 1493 Luis XI expulsó a los judíos de Arlés, pero esa fecha era falsa, pues, además de que para entonces Luis XI estaba muerto, los judíos de esa región fueron expulsados en 1498, y por Carlos VIII. Todo el texto de Bouis estaba plagado de inexactitudes cronológicas que lo invalidarían completamente. Pero, en cualquier caso, Graetz se preguntaba por los motivos que llevaron a Bouis a utilizar las cartas españolas, y encontraba la respuesta en el hecho de que la obra hubiera sido publicada en Aviñón. Era la situación de los judíos en esa ciudad, y no la situación en Arlés, lo

(C) Ediciones Universidad de Salamanca / ®@ Stud. his., H. ${ }^{a}$ mod., 38, n. 2 (2016), pp. 467-502 
que explicaría la inclusión de las cartas en la obra. Según Graetz, algunos clérigos fanáticos, entre los que se encontraría Bouis, no toleraban la presencia judía en Aviñón, por lo que presionaban para que el papa optara por expulsarlos. Ese sería el objetivo de la introducción de las cartas en la obra: evidenciar la maldad de los judíos y estimular su expulsión de la ciudad papal ${ }^{20}$.

\section{Sicroff y Caro Baroja, Silí́ceo y Simancas}

Entre finales del siglo xIx, y hasta mediados del siglo siguiente, no encontramos gran novedad en la historiografía que tocó el tema. Efectivamente, las referencias a la correspondencia que cabe encontrar en obras de la primera mitad del siglo xx, tales como las de Isidoro de Hoyos, Henry Charles Lea o Serrano y Sanz, no hacen sino repetir lo ya conocido ${ }^{21}$. Sin embargo, poco a poco se fueron realizando más aportaciones.

En 1922, Mario Méndez Bejarano sacó a relucir una nueva copia de las cartas, esta vez sacada de un manuscrito sin especificar de la Biblioteca de la Real Academia de la Historia. Ambas, así como el texto posterior acerca de cómo el arzobispo Silíceo las usó en su causa en favor del establecimiento del estatuto de limpieza de sangre de la catedral de Toledo, eran muy semejantes a las ya conocidas hasta entonces, pero no totalmente iguales. Sin embargo, por lo que respecta al conocimiento de la autoría, el motivo o la autenticidad de las cartas, Méndez Bejarano no hacía aportación alguna ${ }^{22}$.

En lo que se refiere al conocimiento de esos aspectos fundamentales de la correspondencia -origen, autoría y objetivo-, las principales aportaciones se realizaron pasados los años 50; aunque también es verdad que, en una fecha tan tardía como 1954, Nicolás López Martínez, siguiendo la tendencia general de su libro sobre los «judaizantes castellanos», se mostraba aún algo reticente a la hora de aceptar que las cartas fueran falsas ${ }^{23}$. Muy al contrario, al año siguiente, Antonio Domínguez Ortiz, en su estudio pionero sobre los conversos de origen judío en

20. Graetz, H.: «But réel de la correspondance échangée vers la fin du xve siécle entre les juifs espagnols et provençaux et les juifs de Constantinople», Revue des Études Juives, 19, 1889, pp. 106-114.

21. Hoyos y de la Torre, I.: Los judíos españoles en el Imperio Austríaco y en los Balkanes. Madrid, 1904, p. 21-22; LEA, H. C.: A history of the Inquisition of Spain. 4 vols., Londres, 1906-1907, vol. 1, pp. 132-133; SERrano y SANZ, M.: Orígenes de la dominación española en América. Tomo Primero. Madrid, 1918, p. LXVII, esp. nota 1.

22. Méndez Bejarano, M.: Histoire de la juiverie de Séville. Madrid, 1922, pp. 266-267.

23. López Martínez, N.: Los judaizantes castellanos y la Inquisición en tiempo de Isabel la Católica. Burgos, 1954, p. 362, nota 316.

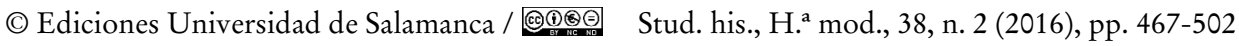


Castilla, las consideraba una falsificación evidente, y las situaba al mismo nivel que otras falsificaciones de la época, como las realizadas por Jerónimo Román de la Higuera ${ }^{24}$.

Una de las principales aportaciones realizadas durante esos años fue la de Albert Sicroff. En su también pionero estudio sobre las polémicas acerca de los estatutos de limpieza de sangre en España, hizo varias afirmaciones con respecto a este tema que van a venir a consolidar la idea de que detrás de las cartas estaba la mano del arzobispo Silíceo. Efectivamente, en su análisis del llamado Libro de causas que el arzobispo envió en el verano de 1548 al emperador Carlos V y al Consejo Real de Castilla para justificar la necesidad de introducir el estatuto de limpieza de la catedral de Toledo, Sicroff señaló que:

Para apuntalar con pruebas históricas su afirmación de la solidaridad de los judíos entre sí, el Arzobispo Silíceo no vacila en referirse a una correspondencia, que hoy parece totalmente inventada, y lo que es más, sería una fabricación suya, entre los judíos de Constantinopla y los de España, en el momento de la expulsión de estos últimos en 1492. Según este intercambio de cartas, los judíos españoles se hubieran aconsejado con sus hermanos de Constantinopla en el dilema que tenían que resolver: someterse al bautismo o sufrir la expulsión. Se les aconsejó entonces fingir la conversión de suerte que, bajo la apariencia de cristianos, pudieran trabajar para expulsar a los otros cristianos de sus iglesias y vengarse así de haber sido ellos mismos echados de sus sinagogas. Los cristianos nuevos siguieron este consejo-Silíceo lo ve con claridad-, esforzándose de modo constante en obtener los beneficios eclesiásticos sobre todo cuando un cristiano viejo había ya presentado su candidatura.

En apoyo de su afirmación, Sicroff citaba el folio 15 vuelto de la copia del documento del arzobispo que se encontraba en el manuscrito espagnol 354 de la Biblioteca Nacional de Francia. Tras ello, en nota al pie, realizaba un pequeño resumen de los estudios que habían tratado este tema, citando a Adolfo de Castro, a Isidore Loeb, así como la copia de las cartas contenida en La silva curiosa. A continuación, comentaba las palabras de Castro acerca de la autoría de Silíceo y que, «desgraciadamente no aporta ninguna prueba en apoyo de su afirmación». Señalaba también que había encontrado copias de las cartas en el mismo manuscrito espagnol 354 -que hablaba de los judíos de Babilonia, y no de los de Constantinopla-, así como en el 721 de la Biblioteca Nacional de España. Igualmente, recordaba que en la defensa del estatuto de limpieza de la catedral de Toledo que, a principios del siglo xviI, escribió Baltasar Porreño, se hablaba de un episodio

24. Domínguez Ortiz, A.: La clase social de los conversos en Castilla en la Edad Moderna. Madrid, 1955, p. 213.

(C) Ediciones Universidad de Salamanca / ®@ Stud. his., H. ${ }^{a}$ mod., 38, n. 2 (2016), pp. 467-502 
semejante, en el que un padre judío, en el momento de la expulsión, aconsejó a su hijo una conversión fingida para infiltrarse en la nobleza y la Iglesia ${ }^{25}$. Así, a tenor de lo sostenido por Sicroff, parecía claro que, o bien el propio arzobispo de Toledo había tenido que ver en la fabricación de las cartas, o, al menos, ya las conocía, pues las citaba explícitamente. De manera semejante, Sicroff afirmaba que, en 1575, el obispo Diego de Simancas, en su obra de defensa del estatuto de Toledo, se refirió también a la correspondencia, la cual consideraba que, aun si fuera falsa, reflejaba la realidad ${ }^{26}$. Finalmente, Sicroff parecía decantarse definitivamente por la tesis de la autoría de Silíceo, pues, en el contexto de su análisis de la obra de Francisco de Torrejoncillo, se refería de nuevo a la correspondencia y afirmaba de forma rotunda que «fue invención de Silíceo» ${ }^{27}$.

Con respecto al papel desempeñado por Silíceo en la historia de la correspondencia, el problema de la interpretación de Sicroff estaba en que se basaba en una lectura errónea del mencionado manuscrito espagnol 354, acerca del cual, ya en 1844, Eugenio Ochoa había dicho que «está tan maltratado que solo con suma dificultad puede leerse, y aun eso no siempre» ${ }^{28}$. Efectivamente, el manuscrito se encuentra muy deteriorado, especialmente en la parte inferior de las hojas, muy afectada por la humedad. Es precisamente ahí donde se encuentra el fragmento al que se refería Sicroff, el cual es prácticamente invisible, lo que indudablemente le impidió realizar una lectura correcta. En realidad, el fragmento no dice lo que él creía. Afortunadamente, el documento del arzobispo se ha conservado en muchas copias, y en casi todas ellas - no en todas-aparece el mismo texto -con variaciones insignificantes-, el cual reza así:

Ítem por cosa pública se tiene que, al tiempo que los judíos eran hechados de España por los Reyes Cathólicos de gloriosa memoria, algunos de ellos que fueron tenidos por sabios dixeron que, pues a ellos los hechaban de sus synagogas, ellos hecharían en breve tiempo a los christianos de su Iglesia. Y así lo experimentamos cada día, porque, por fas o por nefas, procuran de alcançar los benefficios y dignidades de ella, y quando con algún christiano viejo litigan, aunque no tengan justiçia, le fatigan hasta aver el tal benefficio sobre que pleitean ${ }^{29}$.

25. Sicroff, A.: Los estatutos de limpieza de sangre: controversias entre los siglos XV y XVII. Madrid, 1985, pp. 148-149, notas 180 y 181.

26. Idem, p. 198.

27. Idem, p. 203.

28. OсноA, E.: Catálogo razonado de los manuscritos españoles existentes en la Biblioteca Real de París. París, 1844, p. 579.

29. Estatuto de la Sancta Iglesia de Toledo. Biblioteca Nacional de España, ms. 10608, fols. $53 \mathrm{v}-54 \mathrm{r}$.

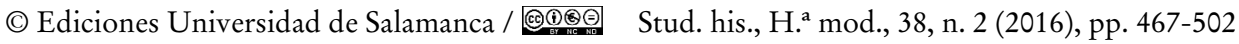


Como se ve, ninguna referencia a las cartas. El arzobispo hablaba únicamente de un rumor, referido a lo que supuestamente dijeron unos sabios judíos -que ni siquiera eran extranjeros-, acerca de echar a los cristianos de su Iglesia. Nada más. Es muy cierto que en el texto del arzobispo se encuentra una temática semejante a la que aparece en la correspondencia, una preocupación por la, a su juicio excesiva, presencia de descendientes de conversos en la Iglesia, y por la existencia de «jueçes, abogados, regidores, diputados, escribanos, arrendadores, recatones y logreros desta casta de judíos», así como «médicos, boticarios, zirujanos, que ya por nuestros pecados no se hallan sino desta casta», los cuales, «según es fama, no toman estos offiçios sino para matar christianos viejos» ${ }^{30}$. Pero en cuanto a las cartas, no hay ni rastro.

Tampoco en la obra del obispo Simancas hay una referencia a la existencia de la correspondencia de la que nos estamos ocupando. Sin embargo, el contenido del pasaje al que se refirió Sicroff es muy parecido al contenido de la correspondencia. Efectivamente, en él casi todo es igual a lo que aparece en las cartas: se mencionan casi los mismos oficios y su ocupación se identifica con casi los mismos propósitos perversos. Pero, en cambio, no se menciona Constantinopla, sino a las «sinagogas de otros países», y en ningún momento se habla de la existencia de las propias cartas. El obispo se refería únicamente a la existencia de una historia que corría por España, la cual él no consideraba muy creíble. Solo desde una interpretación anacrónica, a partir de un conocimiento previo de las cartas, se puede deducir que el obispo se refería a la correspondencia apócrifa que hoy conocemos ${ }^{31}$.

Poco después de Sicroff, Julio Caro Baroja se refirió también a este tema en su gran estudio sobre los judíos en la España moderna y contemporánea. En primer lugar, lo hizo discutiendo la cuestión, tan presente en la tradición antijudía europea, de la «consigna»; es decir, la creencia en que los judíos actuaban todos a una, como guiados por las órdenes de una autoridad superior. Caro Baroja señalaba que tal idea se encontraba implícita en la correspondencia que nos ocupa y que esta se difundió por España en la época en la que el arzobispo Silíceo trataba de imponer el estatuto de limpieza de la catedral de Toledo. Apuntaba también que algunos historiadores, como Castro, habían acusado al propio arzobispo de haberlas fabricado, mientras que en algún manuscrito se decía que fueron «halladas en su época» -en realidad, como mencionamos, el manuscrito del Libro verde decía claramente que fueron halladas por él-32.

30. Vid. Idem, fols. $49 \mathrm{v}-50 \mathrm{r}$.

31. Vid. Simancas, D.: Defensio statuti toletani. Amberes, 1575, pp. 18-19. La edición de 1573 difiere bastante de la de 1575 y no incluye el pasaje en cuestión.

32. Caro Baroja, J.: Los judíos en la España moderna y contemporánea. Vol. 1, 4. a ed., Tres Cantos, 2000, pp. 423-424.

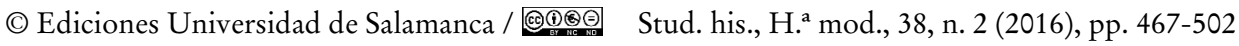


Más adelante, Caro Baroja volvió a este asunto. No lo hizo, -a diferencia de Sicroff-, en el marco de su análisis del Libro de causas del arzobispo Silíceo, sino en su breve estudio de la mencionada obra del obispo Simancas. En ella, Caro Baroja encontraba una referencia más explicita que la encontrada por Sicroff. Mencionaba una «alusión a la supuesta consulta al archisinagogo de Constantinopla»; aunque, según él, Simancas no la daba «como del todo fidedigna» ${ }^{33}$. En realidad, en la obra del obispo no se mencionaba al tal «archisinagogo», y, como hemos dicho, tampoco se mencionaba a Constantinopla. Caro Baroja, en cualquier caso, veía, como Sicroff, una mención expresa de las cartas en la obra del obispo Simancas, lo cual, a nuestro juicio, es resultado de una aproximación anacrónica al texto.

Posteriormente, en cambio, Caro Baroja aseguraba, sin dar más detalles, que las cartas habían pasado a las demás obras a partir del Libro de causas de Silíceo. Fuera como fuera, lo que parecía claro es que, según él, existía una referencia explícita a las cartas en la obra de Simancas, y, si bien en su análisis del documento del arzobispo Silíceo no mencionaba nada al respecto, sí afirmaba posteriormente que en él se encontraban las cartas, y que estas circularon en su época ${ }^{34}$. Pero, como hemos dicho, en ninguno de los dos textos se encuentran las cartas, ni referencia alguna a ellas. Lo que sí se da en ambos es una semejanza en los temas tratados, en las acusaciones anticonversas, muy semejantes a las que se desprenden de la lectura de las cartas; una semejanza que ha hecho que autores como Sicroff, Caro Baroja, y muchos otros tras ellos, hayan visto esa referencia explícita que, en realidad, no se halla.

En este momento -mediados del siglo xx-, a falta de la correspondencia original, y en vista de que ninguna de las copias que hasta entonces se conocían podía fecharse de manera exacta, resultaba evidente que solo se podía establecer el momento aproximado del origen de las cartas a partir de testimonios indirectos. La mayoría de los autores parecía apuntar en dirección al arzobispo Silíceo. Según algunos, como Castro, el propio arzobispo las habría fabricado. Según otros, aunque no fueran obra de Silíceo, este sí las había incluido en la documentación que envió a Roma y al Consejo Real de Castilla para defender su estatuto de limpieza. Finalmente, según otros, en la documentación del arzobispo solo cabía encontrar una mención, aunque bien explícita, a la correspondencia. Pero, en definitiva, seguía sin haber respuesta clara para las principales preguntas: ¿cuándo se creó exactamente la correspondencia que ha llegado hasta nosotros?, ¿de quién fue obra?, ¿qué motivos llevaron a su creación?

33. Idem, vol. 2, 4. ${ }^{\text {a }}$ ed., 2005 , p. 430.

34. Idem, pp. 431-432.

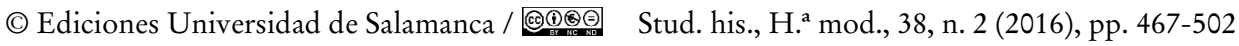




\section{LITERATURA SATÍRICA Y POLÍTICA ANTICONVERSA}

A pesar de que la tendencia mayoritaria entre los historiadores ha sido la contraria, ha seguido habiendo quien ha considerado que la correspondencia tenía un origen literario, cómico, de entretenimiento. Así por ejemplo, a finales de los 60, Norman Cohn, en su gran estudio sobre la historia de la creencia en la conspiración judía internacional, abogaba por esta teoría. En las líneas que dedicó a la correspondencia en su versión francesa -esto es, de los judíos de Arlés-, señalaba que las cartas probablemente «se escribieron en un principio en España como comentario satírico sobre los marranos», y recalcaba: «de lo que no cabe duda era de que su propósito era burlón» ${ }^{35}$.

En la misma línea, pero casi treinta años después, Ángel Gómez Moreno, en el contexto de su estudio sobre las relaciones literarias del Lazarillo de Tormes, sacó a relucir una nueva copia de la correspondencia, la que se contenía en el manuscrito 570 de la Biblioteca del Palacio Real de Madrid, formado por un conjunto misceláneo de textos literarios. Gómez Moreno, siguiendo la estela de Morel-Fatio -aunque sin citarlo-, consideraba la correspondencia como una obra literaria; en su opinión, un ejemplo del género epistolar cómico-burlesco que, desde finales del siglo xv, había disfrutado de gran éxito en España e Italia. Según este autor, en el conjunto de las cartas «impera la técnica tradicional de engaño/ desengaño (fundamental en muchos chistes)», que lleva a un paulatino descubrimiento por parte del lector de que lo que se le está contando es mera ficción. De la constatación final de la falsedad era de lo que surgía la risa. Pero, a la vez, apuntaba el autor, «la efectividad de esta técnica es tal que, incluso tras leer ambas epístolas, habrá aún quien no sepa si lo que tiene delante es un par de documentos auténticos o un pasatiempo literario». Y, efectivamente, Gómez Moreno traía a colación el manuscrito del Libro verde de Aragón de la Biblioteca Colombina, en el que las cartas parecían ser tomadas muy en serio. También citaba la obra de Julián de Medrano y la discusión de Castro, Loeb y Sicroff, pero no se detenía a discutir la cuestión de la autoría. Desde su punto de vista, la correspondencia era una muestra de cómo en esa época se dio una "paulatina incorporación de las formas literarias de realitate al ámbito de la ficción» ${ }^{36}$. ¿Estábamos entonces ante una obra literaria, una mera ficción con objetivo burlesco, que había sido tomada demasiado en serio por algunos? ¿O quizás algunos, sabedores de la ficción, habían decidido utilizarla para sus fines tratando de darla a conocer como si se

35. Cohn: op. cit., p. 46.

36. Gómez Moreno, Á.: España y la Italia de los humanistas. Madrid, 1994, pp. 184-190.

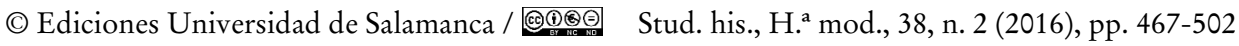


tratara de documentación auténtica, añadiendo, para ello, la historia del hallazgo por parte de Silíceo?

John Beusterien ha seguido la misma tendencia que Gómez Moreno. Este autor también consideraba que las cartas tenían un origen literario, que no eran más que una «broma del siglo Xvi convertida en una verdad del siglo XvII», dando origen a la que, según el autor, era la «primera descripción de una conspiración judía internacional en Occidente».

Soslayando el debate existente hasta entonces, e ignorando cualquier otra posibilidad, Beusterien consideraba abiertamente que el autor de las cartas fue Julián de Medrano -al que, por razones que desconocemos, siempre llamaba «Medroso»-. Medrano, señalaba, insertaba las cartas en su Silva curiosa, una miscelánea como las que por entonces estaban de moda, semejante a las escritas por Antonio de Torquemada, Luis Zapata o Pedro Mexía. Las incluía en la sección de su libro dedicada a cuentos graciosos, lo que implicaba que el autor las consideraba humorísticas, ingeniosas. Seguían, en definitiva, el modelo engaño-revelación del que había hablado Ángel Gómez. Este carácter burlesco le habría parecido claro a cualquier lector educado de la época, pues en las cartas aparecían referencias a España, algo que, en unas cartas que supuestamente fueron escritas a finales del siglo xv, no habría tenido sentido. Y también se hablaba de un príncipe de los judíos de España, que era notorio que nunca había existido. Además, se firmaba con el nombre de Chamorra, que, según Beusterien -quien no tenía en cuenta lo que otros autores habían dicho acerca del sentido de la palabra, y lo que Graetz había apuntado acerca de la familia Chamorro de Zaragoza que aparecía en el Libro verde-, tendría el sentido de «burro castrado», lo cual habría tenido evidentes connotaciones cómicas en la época.

Por lo demás, el género epistolar era muy utilizado en la época con este objetivo de entretenimiento cortesano. Ejemplo de ello, eran, según el autor, las cartas de Francisco López de Villalobos, Francés de Zúñiga o Fernando del Pulgar -a quien el autor llama «bufón de corte», quizás confundiéndolo con Zúñiga-, así como la que la mujer de Sancho Panza envió a este en el capítulo 36 de la segunda parte del Quijote, que no estaría dirigida realmente a Sancho, sino al divertimento de los duques anfitriones del caballero de La Mancha y su escudero ${ }^{37}$.

Debido a ese carácter de obras literarias hechas para el entretenimiento, las cartas se incluyeron en alguna miscelánea manuscrita de obras poéticas o cómicas,

37. Como recordará el lector, en realidad la carta del capítulo 36 la dirige Sancho a su mujer Teresa, y no al revés, como afirma Beusterien. Más adelante aparecen nuevas cartas, incluyendo una en el capítulo 52 dirigida -esta sí- por Teresa Panza a su marido, la cual, efectivamente, es leída en voz alta para entretenimiento de la duquesa.

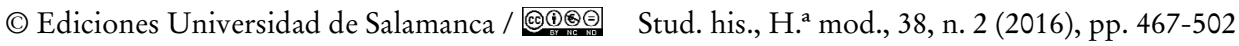


como el manuscrito 570 de la Real Biblioteca de Madrid, que Beusterien, acertadamente, pero sin aclarar por qué motivo, consideraba un poco posterior a la obra de Medrano.

Según Beusterien, parecía que, en la transformación de las cartas de obra cómica a documento histórico tenido por auténtico, tuvo una importancia central su inclusión en el Libro verde de Aragón. Como ya hemos visto en repetidas ocasiones, las cartas aparecen en una de las copias manuscritas de ese texto, en concreto la de la Biblioteca Colombina. No aparecen fechadas, aunque, desde Rodrigo Amador de los Ríos, se sabe que son un añadido posterior a 1575. Sin embargo, Beusterien, no sabemos con qué criterio, supone que las cartas del Libro verde son de «una década o así después» de su aparición en las dos misceláneas anteriores, es decir, de hacia 1593. También supone este autor que las cartas, al igual que las historias antijudías que las acompañaban en la copia de la Biblioteca Colombina -la muerte del maestre Épila, la historia sobre las razones de la expulsión de los judíos-aparecían en «muchos libros verdes», lo cual, ateniéndonos al contenido de las demás copias existentes, no parece correcto $^{38}$. En cualquier caso, dejando aparte estas consideraciones acerca de la fecha y composición del Libro verde, lo importante, según este autor, es que, mediante su inclusión en ese manuscrito, las cartas denotaban haber adquirido otro carácter. Ahora estaban dirigidas a un público predispuesto a ver en ellas testimonios auténticos de una verdadera conspiración judía internacional.

En el siglo xvII, afirmaba Beusterien, las cartas seguramente todavía provocaban risa, pero ya no formaban parte de obras dedicadas al esparcimiento, sino que empezaron a ser usadas como un documento histórico auténtico. A ello contribuyó que el Libro verde atribuyera el hallazgo de las cartas a Juan Martínez Silíceo. Así, ponía el ejemplo de Baltasar Porreño, quien, según este autor, en su defensa del estatuto de la catedral de Toledo, incluyó también una copia de las cartas, y decía que había examinado los originales. Desconocemos en qué se basaba Beusterien para afirmar tal cosa, pues no daba referencia alguna. Ninguno de los anteriores historiadores que había tratado el tema había afirmado algo así. Y es que, de hecho, en realidad Porreño ni reprodujo las cartas, ni afirmó haberlas visto. Simplemente repitió lo que ya habían dicho el arzobispo Silíceo y el obispo Simancas. Si bien

38. De las copias del Libro verde que han sobrevivido, solo la de la Biblioteca Colombina contiene los añadidos de las historias antijudías. Vid. al respecto El libro verde de Aragón. Edición de Monique Combescure, Zaragoza, 2003.

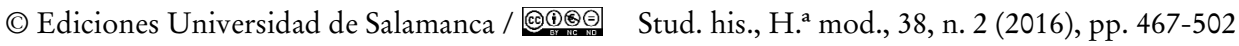


es verdad que convirtió en hecho fehaciente lo que para el obispo de Zamora no era más que un rumor poco creíble ${ }^{39}$.

Finalmente, Beusterien mencionaba que la correspondencia apareció en las obras que ya citamos en su momento: las de Villar Maldonado, Gavilán Vela, Quevedo y Torrejoncillo. Gracias a ello, las cartas cómicas escritas para el divertimento de la corte se convirtieron finalmente en documentos tenidos por fidedignos ${ }^{40}$.

En cualquier caso, la atribución de las propias cartas -o, al menos, la atribución de su difusión- a Silíceo, ya fuera por influencia de las ideas de Castro, ya fuera por lo que Sicroff y Caro Baroja habían sostenido, parece que fue aceptada por muchos autores durante los siguientes años ${ }^{41}$. Con ello, parecía imponerse el criterio de que las epístolas fueron escritas con un objetivo que no fue, ni mucho menos, literario, satírico o jocoso, sino totalmente político: un arma en la lucha por la legitimación de la discriminación social de los cristianos descendientes de conversos. Como diría Netanyahu, la espuria carta de los judíos de Constantinopla no es por tanto «una curiosidad literaria o señal de ignominia del cardenal que la utilizó», sino un documento de la mayor significación» que no solo venía a sostener las acusaciones anticonversas del propio arzobispo, sino que repetía las que ya en su momento realizaron los defensores de la sentencia-estatuto de Pedro Sarmiento en $1449^{42}$.

39. Vid. Porreño, B.: Defensa de el estatuto de limpieza, que fundo en la sancta Iglesia de Toledo el Cardenal, y Arçobispo Don Juan Martínez Silíceo. Biblioteca Nacional de España, ms. 5910, pp. 122 y 180.

40. Beusterien, J.: «The Spanish “Jewish Conspiracy” Letters», The Monographic Review, 22, 2006, pp. 33-45.

41. Vid., por ejemplo, Carrasco, R.: «La nueva Jerusalén y la memoria judeoconversa (siglos XVI-XVII)», en CARrasco, R. et al. (Eds.): La Inquisición y la sociedad Española. Valencia, 1996, pp. 9-30; Netanyahu, B.: Los orígenes de la Inquisición en la España del siglo XV. Barcelona, 1999, pp. 963 y ss; Álvarez Chillida: op. cit., pp. 45-46; Amran, R.: «Calumnias y falsificación histórica: dos casos de correspondencia apócrifa relacionadas con judíos hispanos durante el medioevo", Cabiers de Linguistique Hispanique Médiévale, 29, 2006, pp. 317-326; Quero, F.: Juan Martínez Silíceo (1486?-1557) et la spiritualité de l'Espagne pré-tridentine. París, 2014, p. 230. Vincent Parello, sin embargo, solo afirma que Silíceo citó las cartas en su «dossier» al Consejo Real de Castilla; Vid. sus «De l'antisémitisme théologique médiéval à l'antisémitisme économique: le cas de l'allégation du bachelier Pedro Ortiz (1546)», Mélanges de la Casa de Velázquez, 30 (2), 1994, pp. 7-28; y Les judéo-convers: Tolède, Xve-Xvie siècles. París, 1999, pp. 124-125. Por su parte, Norman Roth es el único autor, por lo que sabemos, que atribuye la fabricación de la correspondencia a «oficiales de la Inquisición»; Vid. su Conversos, Inquisition, and the expulsion of the Jews from Spain. Madison, 2002, p. 295.

42. Netanyahu: op. cit., p. 966.

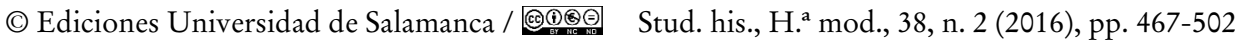


Mientras tanto, entre finales de los años 90 y principios de los 2000 , vieron la luz, por un lado, una nueva edición de La silva curiosa de Julián de Medrano, realizada por Mercedes Alcalá Galán, basada en la princeps de 1583; y, por otro, una nueva edición del Libro verde de Aragón, realizada por Monique Combescure a partir del manuscrito de la Biblioteca Colombina, pero comparado con el resto de manuscritos. En ambos casos, obviamente, se incluían las cartas. En el segundo caso, Combescure confirmaba lo que ya señaló Rodrigo Amador de los Ríos: que los documentos que aparecen a partir del folio 74 eran añadidos posteriores a 1575 , «copias de libelos que circulaban independientemente del Libro verde» ${ }^{43}$.

Para cerrar este epígrafe, nos centraremos en la aportación realizada por Íñigo Pérez Ochoa. En este caso, el trabajo venía a arrojar luz sobre un documento sobre los judíos de Tudela que incluía también la correspondencia que nos ocupa, además de la historia de cómo el arzobispo Silíceo la encontró y la usó ante Roma en su pleito por el establecimiento del estatuto de limpieza de la catedral de Toledo. El documento en cuestión, conocido como «el padrón» de los judíos de Tudela, tenía su origen en 1510, cuando los conversos de la ciudad navarra recaudaron 650 ducados como pago al rey para verse libres de la persecución inquisitorial. El documento, por tanto, recogía los nombres de los contribuyentes al pago. Más tarde, tal lista había sido utilizada a modo de «libro verde» para mantener viva la memoria de las familias de origen converso. A ese documento base se le habían añadido más tarde otros documentos, entre ellos las cartas. Por lo que respecta a estas, el trabajo de Pérez Ochoa resultaba útil a la hora de establecer en qué momento aproximado se incluyeron en el documento. Del «padron» se conservaban tres copias, de las cuales, sólo contenían los documentos añadidos la conservada en el Archivo General de Navarra y la del Archivo Municipal de Tudela, que ahora Pérez Ochoa transcribía. La primera era una copia de 1642, y la segunda de entre 1653 y 1654 . Dentro del manuscrito, las cartas se situaban entre un documento fechado en 1561 y otro fechado en 1610, luego es lógico suponer que éstas se añadieron en un momento indeterminado de ese periodo ${ }^{44}$.

\section{Las cartas en Francia y Portugal}

Como hemos visto, desde los tiempos del debate en la Revue des Études Juives, la cuestión de por qué el abate Bouis introdujo las cartas en su obra de

43. Medrano: op. cit., pp. 224-225; El libro verde de Aragón, op. cit., pp. 210-211, la cita en p. LXVI.

44. Pérez Ochoa, Í.: «El "Padrón” y la "Manta" de Tudela: documentación acerca de los judeoconversos y la Inquisición en Navarra», Sefarad, 74 (2), 2014, pp. 389-426.

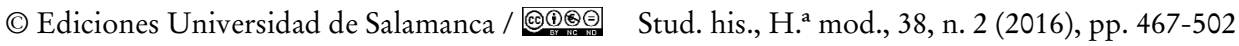


1641, y si obedecía o no a la situación histórica real de los judíos de Provenza y sus descendientes, ha estado presente en la historiografía. Pero no fue hasta 1945 cuando se empezó a saber más sobre esta cuestión. Fue entonces cuando A. Z. Aeskoly aportó datos verdaderamente interesantes sobre la historia de la correspondencia en Francia, aclarando, de paso, el porqué de la inclusión de las cartas en la obra de Bouis.

Aeskoly retomaba el tema de la carta de los judíos de Arlés y la respuesta de los de Constantinopla, tal y como fueron reproducidas en la obra del padre Bouis, recordando su falsedad, su origen español, y señalando que eran una provocación contra los conversos españoles tras la expulsión de 1492. A diferencia de lo que habían afirmado Loeb y Graetz, Aeskoly aseguraba que la versión francesa de las cartas tenía una motivación basada en la situación real de la Provenza de los siglos XVI y XVII. Al igual que en el caso español, estaban dirigidas contra la población conversa de Provenza, tras la expulsión de los judíos de la zona después de la anexión al reino de Francia a finales del siglo xv. Según esto, la expulsión de los judíos de Provenza hizo que muchas familias aceptaran el bautismo. Estas familias, con el tiempo, fueron ascendiendo socialmente y ocupando puestos de poder dentro de la sociedad provenzal, incluso en la nobleza. Esto provocó una reacción de rechazo semejante a la que se produjo en España. A principios del siglo XVII se llegaron a presentar quejas ante el rey pidiendo que se impusieran límites al acceso de los conversos a determinados cargos. Aeskoly hablaba en particular del memorándum enviado por de Monier al rey Enrique IV, en el que se mencionaban los supuestos consejos de los judíos de Constantinopla, y donde argumentaba que los judíos de Provenza los habían seguido, y que por eso se habían convertido. Monier llegaba a pedir que los conversos fueran expulsados, y sus propiedades confiscadas. Era en este contexto en el que cabía entender la introducción de las cartas en la obra de Bouis.

Por otra parte, Aeskoly señalaba que, a principios del siglo xviII, el padre Barcillon de Mauvans realizó una lista de la nobleza de Provenza en donde se destacaba el origen judío de algunas familias -algo semejante a lo que encontramos en el Libro verde de Aragón y el Tizón de la nobleza española-, con el mismo objetivo que de Monier un siglo antes. La lista de familias venía precedida de un prólogo sobre la nobleza y sobre la historia de los judíos de Provenza en el que, de nuevo, se sacaba a relucir la correspondencia de los judíos de Constantinopla, que otra vez se esgrimía como prueba de los intereses espurios que los judíos habían tenido a la hora de aceptar el bautismo, y del peligro que corrían los cristianos de caer en sus manos.

En definitiva, los documentos aportados por Aeskoly testimoniaban la existencia de una situación en Provenza semejante a la existente en España. Si bien a menor escala, y con escaso éxito, también allí se había reaccionado con hostilidad

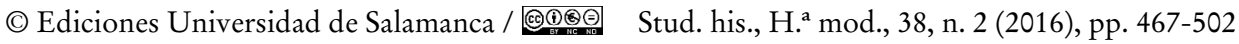


ante el ascenso social de los conversos, y se había pedido reiteradamente una legislación que permitiera su marginación social. Era eso lo que había propiciado que también allí se manejaran las cartas ${ }^{45}$.

También la conexión de las cartas con la historia de Portugal ha estado muy presente en la historiografía. Su inclusión en la obra de Costa Matos era conocida, pero, desde finales del siglo xIX, se realizaron nuevas aportaciones que vinieron a incrementar de forma importante nuestro conocimiento acerca de este aspecto de la historia de la correspondencia. Ya en 1895 Joaquím Mendes dos Remédios, en su historia de los judíos de Portugal, aportó algunos datos importantes ${ }^{46}$. Este autor citaba al principio de su obra un manuscrito en el que se decía que unos cristianos viejos de Portugal encontraron tres cartas destinadas a los judíos de aquella nación en las que podían leerse cosas como las contenidas en la correspondencia entre los judíos de España y los de Constantinopla. La carta, decía el manuscrito, venía trasladada en unas memorias de un «religioso dominico» escritas hacia 1625. Mendes dos Remédios parecía dar al documento el carácter de auténtico testimonio del modo de ser de los judíos, pero, más allá de esto, lo importante es que mostraba que en Portugal habían circulado también cartas semejantes a las que circularon por España y Francia. Dada su semejanza con las ya conocidas, cabía preguntarse cuál era la relación que existía entre ellas.

Más tarde, ya a principios del siglo xx, Joao Azevedo, aportaría algunos datos más, que vendrían a reforzar lo que ya apuntó Mendes dos Remédios. Después de hacer referencia a las cartas, que consideraba que «no merecen más crédito que los Protocolos de los ancianos sabios de Sión», citaba este autor, en una nota al pie, un documento realizado por un obispo anónimo contrario a un perdón general de los encausados por la Inquisición de Portugal. En ese documento se leía que entre los conversos se cumplía lo que «un judío de Constantinopla» decía «a los de su nación de estas partes», es decir: que «hiciesen a sus hijos médicos y eclesiásticos, para que fuesen señores de las almas y los cuerpos de los cristianos». Citaba asimismo un Tratado em que se prova serem christãos fingidos os da nação que viuem em Portugal, sin fecha, pero sin duda posterior a 1600, en donde igualmente se mencionaba la correspondencia ${ }^{47}$.

45. Aeskoly, A. Z.: «The correspondence between the Jews of Spain and Provence and the Jews of Constantinople, and the History of the Marranos of Provence (en hebreo)», Zion, 4 (1), 1945, pp. 102-139.

46. Mendes dos Remédios, J.: Os judeus em Portugal, I. Coimbra, 1895, p. 28, nota 23.

47. Azevedo, J. L.: História dos cristãos novos portugueses. Lisboa, 1921, pp. 166-167, 198 nota 1 y 464-465. Vid. también Soyer, F.: Popularizing Anti-Semitism in Early Modern Spain and its Empire: Francisco de Torrejoncillo and the Centinela contra judios (1674). Leiden, 2014, p. 90.

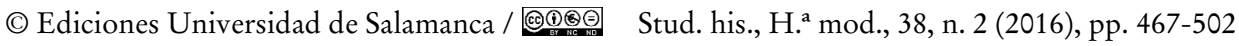


Ya en los años sesenta, Francisco Cantera Burgos sacaría a relucir un documento que vendría a arrojar nueva luz sobre la historia de la correspondencia en Portugal y su conexión con su historia en España ${ }^{48}$. El documento en cuestión resultaba problemático, y volvería a ser retomado y reinterpretado más tarde por otros autores. Se trataba de una carta conservada en el Instituto Valencia de Don Juan que aparecía con el título de «Advertimiento de cierto negoçio sabido por orden de la Inquisiçión de Llerena». Esta había sido enviada, según Cantera Burgos, por el obispo de Plasencia, don Pedro González de Azevedo, entre 1583 y 1591, a una persona influyente de la corte de Felipe II.

En el texto, el obispo relataba cierto episodio ocurrido muchos años antes. Según él, mientras estaba en Portugal, tuvo una reunión con el inquisidor Martín Salvatierra, que en el momento de escribir la carta era obispo de Segorbe. El inquisidor le informó de que dos cristianos que habían estado cautivos en Constantinopla habían hecho declaración de que uno de ellos, que había sido esclavo de un judío, se enteró por medio de la hija de este de que los judíos de Portugal, en el momento de su expulsión del reino, habían escrito a su padre pidiéndole consejo y diciéndole que, dadas las dificultades que pasaban, no habían encontrado mejor forma de sobrellevarlas que hacer a sus hijos médicos y boticarios para, sirviéndose de sus conocimientos, vengarse de los cristianos. El padre les respondió animándolos a seguir actuando de esa manera, y les decía que hicieran a sus hijos sacerdotes para llevar a los cristianos a la idolatría, y también letrados para que pudieran hacerse con sus haciendas. Ambas cartas fueron entregadas por la hija del judío al cautivo, y este las entregó al inquisidor, quien, a su vez, las dio al obispo de Plasencia. Este, por su parte, las mandó al rey don Sebastián I de Portugal para que pusiera remedio al asunto. El rey, influido por las cartas, dispuso que en la universidad de Coimbra se creasen veinte becas en medicina para cristianos viejos, y otras quince para farmacia. El obispo afirmaba igualmente que, con respecto a los jueces, en Portugal había costumbre de que fueran cristianos viejos, y así, decía, lo tenía también dispuesto el Concilio con respecto a los clérigos. Finalmente sugería que se privara a los cristianos nuevos «de toda honra y preeminencia», dado el peligro que suponían para el reino. Todo lo cual pedía que, en cuanto hubiera ocasión, se pusiera en conocimiento del rey.

Cantera Burgos no se extendía más allá en el asunto. No se preguntaba por la verosimilitud de la historia del obispo. Ni siquiera establecía una relación entre lo que se contaba en el documento y la famosa correspondencia que nos ocupa. Pero

48. Cantera Burgos, F.: «El problema de los criptojudíos al escalar el trono Felipe III», en Homenaje al excmo. Sr. Dr. don Emilio Alarcos García. 2 vols., Valladolid, 1967, vol. 2, pp. 633-642.

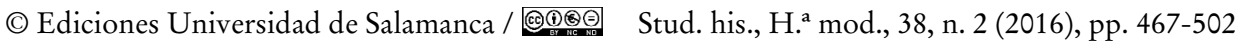


sí parecía que en su interpretación existía un error evidente: Pedro González de Azevedo fue obispo de Plasencia entre 1594 y 1609, luego el documento no podía ser obra suya y, a la vez, datar del periodo 1583-1591, cuando Martín Salvatierra fue obispo de Segorbe.

Habría que esperar a 1988 para que algunos de los errores cometidos por Cantera Burgos en su interpretación del documento se resolvieran, y se estableciera también la relación con la célebre correspondencia. Fue entonces, en efecto, cuando David Goodman resolvió el asunto -sin hacer referencia, dicho sea de paso, al trabajo previo de Cantera Burgos-. Según este autor, en realidad el documento del Instituto Valencia de Don Juan no se redactó por el obispo Pedro González, sino por su antecesor en el cargo, Andrés de Noronha, que fue obispo de Plasencia entre 1581 y 1586. El documento databa, por tanto, de esa época, y la reunión que mencionaba con el inquisidor Salvatierra no tuvo lugar estando el obispo en Portugal por casualidad -como se daba a entender en el caso de Pedro González-, sino porque en esa época -entre 1560 y 1581- Noronha había sido obispo de Portalegre. De hecho, era «Portalegre» lo que decía el documento, y no «Portugal», como había entendido erróneamente Cantera Burgos. Goodman, además, recordaba al lector la vinculación entre la conspiración «destapada» por Noronha y la famosa correspondencia de la que estamos tratando ${ }^{49}$.

En cualquier caso, lo que parecía claro gracias a estos descubrimientos es que, hacia finales del siglo XvI, la correspondencia entre los judíos de España y los de Constantinopla, o el rumor que quizás la había inspirado, se había conocido en una diócesis tan apartada como la de Plasencia, y que ya entonces se establecía su relación con las políticas de limpieza de sangre en Portugal. Pero, además, si hubiéramos de creer al obispo Noronha, tendríamos que afirmar que la correspondencia ya era conocida hacia mediados de los años 60 -cuando Salvatierra fue inquisidor en Llerena-, que estuvo en sus manos y que la puso en conocimiento del rey de Portugal. ¿Pero era la historia del obispo creíble?

Más de un cuarto de siglo después, en 2014, François Soyer volvió a traer a colación el documento del obispo Andrés de Noronha, presentándolo como una «nueva evidencia ${ }^{50}$. En su artículo, tras hacer un resumen de la historia de las cartas y su importancia en la tradición antijudía europea, pasaba a la cuestión de su origen. Sobre esto, mencionaba que su falsedad ya fue demostrada por Isidore Loeb en

49. Goodman, D.: Poder y penuria: gobierno, tecnología y sociedad en la España de Felipe II, Madrid, 1990, pp. 247-248.

50. Soyer, F.: «The Anti-Semitic Conspiracy Theory in Sixteenth-Century Spain and Portugal and the Origins of the Carta de los judios de Constantinopla: New Evidence», Sefarad, 74 (2), 2014, pp. 369-388.

(C) Ediciones Universidad de Salamanca / ®@ Stud. his., H. ${ }^{a}$ mod., 38, n. 2 (2016), pp. 467-502 
1887 -aunque más tarde recordaba que ya Adolfo de Castro había afirmado que eran falsas, y que incluso las había atribuido a Silíceo, aunque sin ofrecer pruebas de ello-. Después señalaba que la primera versión impresa de la correspondencia apareció en la obra de Medrano ${ }^{51}$; pero sostenía, sin aportar ningún dato que lo probara, que «no puede haber duda de que las cartas datan de muchos años antes de que la obra de Julián de Medrano apareciera por primera vez impresa».

El origen de las cartas podía estar, según Soyer, en la controversia que rodeó la introducción del estatuto de limpieza de sangre en la catedral de Toledo por el arzobispo Silíceo. De hecho, afirmaba, la primera referencia a las cartas se encontraba en los documentos de la controversia que estalló entonces entre los detractores y defensores del estatuto. Señalaba, como prueba, que Albert Sicroff ya había mostrado que, entre los muchos libelos que Silíceo esgrimió contra los conversos para justificar el estatuto, había una referencia explícita a las cartas, algo que, como hemos visto, no es cierto. Además, afirmaba que, en la defensa del estatuto de la catedral de Toledo que publicó Diego de Simancas se hacía referencia al «rumor» de que «los conversos de Toledo» consultaron a sinagogas extranjeras tras el decreto de expulsión, las cuales les dieron consejos semejantes a los contenidos en la Carta de los judíos de Constantinopla ${ }^{52}$. Soyer, por tanto, acertaba al contradecir implícitamente lo que en su momento dijo Caro Baroja cuando afirmó que existía en la obra de Simancas una referencia a las cartas, y no a un simple rumor. Sin embargo, olvidaba señalar que el obispo no daba como del todo fidedigna tal historia. Además, al igual que, como vimos, hizo Beusterien años antes -aunque sin citarlo-, afirmaba que también Baltasar Porreño se refirió a las cartas, diciendo que él mismo las había visto, algo que tampoco es correcto ${ }^{53}$.

Soyer decía también que era posible afirmar que no había rastro de las cartas, o referencias a ellas, antes mediados del siglo Xvi, pues las copias manuscritas que existen en las bibliotecas de España, Portugal y Francia, y que, según él, fueron

51. Soyer afirmaba que la primera edición de La silva curiosa fue la de Zaragoza de 1580, cuando, como ha demostrado Alcalá Galán, esta edición es pirata, pues se trata de «la puesta en venta con datos falsos (de fecha, por ejemplo) del resto de la primera edición de 1583", Vid. Medrano, J.: La silva curiosa de Julián de Medrano. Estudio y edición crítica de Mercedes Alcalá Galán, Nueva York, 1998, pp. 3-4, cursiva en el original.

52. En realidad, Simancas no se refería a los «conversos de Toledo», como afirmaba Soyer, sino a los judíos de España en general. Lo contrario no habría tenido sentido, ya que, como se sabe, era precisamente la respuesta de las sinagogas extranjeras a la petición de consejo de los judíos españoles la que recomendaba la conversión. Vid. Simancas: op. cit., pp. 18-19.

53. En el texto de Soyer la obra de Porreño aparece mal citada como Defensa del estatuto de limpieza de sangre que estableció en la Iglesia de Toledo el arzobispo Silíceo o Museo de los reyes sabios que ban tenido las naciones del orbe. Soyer también olvida mencionar la localización del manuscrito al que se refiere.

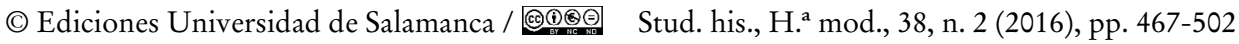



Y LOS DE CONSTANTINOPLA: UNA REVISIÓN CRÍTICA

examinadas por Sicroff, eran todas posteriores a 1550. Esta afirmación se sostenía sin aportar dato alguno que permitiera sostenerla, y sin, al parecer, haber consultado ninguna de las copias manuscritas existentes. Por otra parte, como se recordará, Sicroff, solo mencionaba dos copias: la del espagnol 354 y la del manuscrito 721 de la Biblioteca Nacional de España.

Seguidamente, Soyer pasaba a analizar el documento del obispo Andrés de Noronha. Aquí, si bien mencionaba el trabajo previo de Cantera Burgos y su error de atribución, no mencionaba en ningún momento el trabajo de David Goodman, y presentaba su propia interpretación del documento como si de una novedad se tratase. Lo novedoso, en todo caso, no era la atribución del documento a Noronha -algo que, como vimos, ya hizo Goodman-, sino más bien la manera en la que Soyer concedía credibilidad a la historia del obispo. Efectivamente, a pesar de que en el documento se daba cuenta de un encuentro sucedido veinte años antes, Soyer parecía aceptar que la historia resultaba verídica: que el encuentro se produjo tal y como Noronha relataba, que Salvatierra efectivamente le entregó las cartas, y que aquel las envió al rey de Portugal. El autor incluso consideraba digna de crédito la historia que, a su vez, Salvatierra supuestamente contó a Noronha acerca de los cautivos que estuvieron en Constantinopla y obtuvieron las cartas.

En cualquier caso, no se entendía muy bien por qué razón Soyer consideraba que un documento de hacia 1583-1586 era una «referencia muy temprana» a las cartas, puesto que para entonces ya las había publicado Medrano ${ }^{54}$. Y menos aún se entiende si, como él creía, ya se encontraban referencias a las cartas en los documentos de Silíceo -que eran de 1548-; aunque, como hemos visto, se equivocaba. Solo se entiende si pensamos que, con esa «referencia muy temprana», Soyer no se refería al documento de Noronha en sí, sino a la supuesta reunión de circa 1566-1567 que en él se mencionaba.

Y es que este autor tendía a aceptar que todo lo que el obispo de Plasencia contaba en el memorándum sucedió tal y como ahí se decía. Aceptaba, por ejemplo, que las cartas enviadas al rey tuvieron una importancia central en la introducción de algunas medidas anticonversas en importantes instituciones portuguesas. Aceptaba igualmente que la entrevista con Salvatierra se produjo tal cual se decía en el documento. También que el interrogatorio a los cautivos se produjo efectivamente, y llegaba a elucubrar sobre si fueron quizás estos los que inventaron lo de las cartas. En definitiva, Soyer atribuía una asombrosa fiabilidad al documento, algo que produce cierta perplejidad, teniendo en cuenta lo familiarizado que está

54. Y menos aún se entiende si se tiene en cuenta que Soyer piensa que la primera edición de La silva curiosa es de 1580.

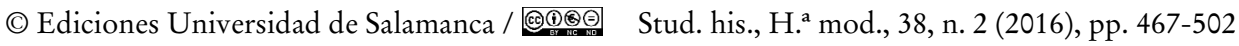


este autor con las leyendas antijudías que corrían por la época, y con los pocos escrúpulos que tenían ciertos prelados de la Iglesia para utilizarlas con el objetivo de legitimar sus posiciones anticonversas ${ }^{55}$.

En cualquier caso, el artículo de Soyer resultaba interesante porque recalcaba la importancia que parecían haber tenido en Portugal historias como las transmitidas por las cartas, y cómo habían sido utilizadas para justificar las medidas anticonversas -ya fuera para legitimar a priori la introducción de estatutos de limpieza de sangre en determinadas instituciones, ya fuera para legitimarlos a posteriori-.

Pero quizás lo más importante del documento del obispo Noronha es lo que ni Cantera Burgos, ni Goodman, ni Soyer, parecían haber detectado. Lo más importante es que Noronha pretendía dar a conocer algo desconocido, una absoluta novedad. Por ello, muy probablemente, lo que nos muestra el documento del obispo de Plasencia es que, lejos de ser algo sobradamente conocido en España, todavía en el periodo 1583-1586 la existencia de la correspondencia entre los judíos de España y los de Constantinopla podía ser tenida por una revelación totalmente novedosa, y que, por tanto, o no se había puesto aún en circulación, o todavía no circulaba de la manera en la que lo haría a partir de la segunda década del siglo Xvir. Pero, en tal caso, la pregunta sería, ¿cómo una historia como la reflejada en las cartas había llegado al obispo de Plasencia y, sin embargo, parecía ser desconocida en la Corte?

Quizás esto se explique a partir de la diferenciación que hemos establecido entre la leyenda antijudía que parecía haberse difundido por España, y de cuya existencia se hizo eco el obispo Simancas, y las propias cartas, tal y como hoy las conocemos. Noronha quizás no pretendía que esa leyenda transmitida por Simancas fuera desconocida en la Corte. De hecho, si hemos de creer al obispo de Zamora, su libro fue bien acogido en la Corte de Felipe II, e incluso el rey lo tenía en su cámara y lo leía ${ }^{56}$. Si es así, quizás lo novedoso no era la historia, sino la pretendida existencia de las propias cartas, que Noronha afirmaba haber visto. Quizás con su memorándum el obispo de Plasencia solo trató de dar verosimilitud a una historia conocida pero poco creíble -recuérdese que el propio Simancas dudaba de su verosimilitud-, con el objetivo, quizás, de obtener apoyos en su intento de introducir un estatuto de limpieza para la catedral de Plasencia ${ }^{57}$. Es posible que ni siquiera conociera las cartas que luego se harían populares entre los

55. Vid. especialmente su Popularizing Anti-Semitism, Op. cit.

56. Simancas, D.: «La vida y cosas notables del señor obispo de Zamora don Diego de Simancas», en Serrano y Sanz, M. (Ed.): Autobiografías y memorias. Madrid, 1905, p. 172.

57. En el propio memorándum Noronha hace referencia a los problemas que le ha acarreado en su diócesis el no querer ordenar a clérigos de origen converso.

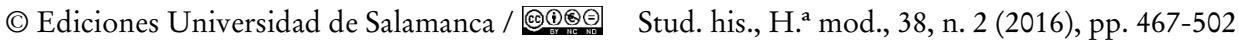


escritores antijudíos. Es posible que él y el autor de las cartas, partiendo ambos de la historia de Simancas, hubieran tratado de hacerla más creíble; uno, inventando esa historia de los cautivos; el otro, inventando las propias cartas. Y es posible que ambos hubieran elegido como destino de la petición de los judíos españoles la ciudad que, para finales del siglo xvi, parecía más evidente: Constantinopla.

\section{Conclusiones}

Hasta aquí nuestro repaso a la bibliografía que se ha dedicado a este tema, o que ha aportado nuevos datos que contribuyen a incrementar nuestro conocimiento acerca del origen y la historia temprana de la correspondencia entre los judíos de España y los de Constantinopla. Si el lector ha llegado hasta aquí, es muy probable que experimente cierta desorientación, dada la acumulación de información. Por esta razón será bueno que realicemos un pequeño resumen de lo dicho y saquemos algunas conclusiones.

En este trabajo hemos mostrado que la correspondencia entre los judíos de España y los de Constantinopla ha ocupado un lugar destacado en la historiografía europea; especialmente en la española, francesa y portuguesa. Ese lugar lo ha ocupado, principalmente, en los estudios sobre la España de los siglos Xv a XVII, sobre todo en los dedicados a la historia de los judíos, de los conversos y sus descendientes, y de la tradición antijudía española. Hemos visto que desde comienzos del siglo xix se afirmó su falsedad y que, a lo largo del siglo, a pesar de que algunos autores siguieron considerándola una expresión inmejorable del carácter artero, traicionero y vengativo de los judíos, se consideró, cada vez más, como expresión de la ideología antijudía y anticonversa.

Sin embargo, por lo que hemos visto, ya desde tiempos de Morel-Fatio se vislumbra una diferencia clara entre los historiadores de la literatura y los historiadores sociales, o dedicados a la historia del judaísmo, en cuanto a la consideración de los objetivos que habría buscado el creador de la correspondencia. Los primeros parecen más proclives a entender la correspondencia dentro de un género de sátira literaria expresada en forma de carta, algo muy extendido en los siglos XVI y XVII. Los segundos, en cambio, solo ven en la correspondencia un objetivo socio-político claro: la legitimación de la discriminación de los conversos y la introducción o mantenimiento de los estatutos de limpieza de sangre.

A nuestro juicio, no debería desecharse a la ligera la idea de que la correspondencia respondió, en su origen, únicamente a un objetivo satírico, humorístico incluso, y no directamente político, como algunos historiadores, desde Graetz hasta el presente, han hecho. Existen precedentes claros de este tipo de literatura satírica con formato epistolar, como la famosa «Carta de privilegio del rey Juan II a un

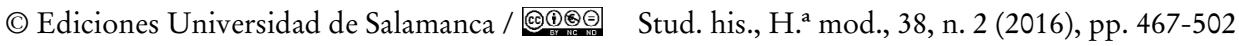


hijodalgo», en la que se tocan temas semejantes, entre ellos el de la ocupación por parte de los conversos de diferentes oficios públicos, su infiltración en la iglesia y su ocupación como médicos, cirujanos y boticarios ${ }^{58}$. Es muy posible, por tanto, que, como defiende Beusterien, lo que empezó siendo una creación estrictamente literaria, terminara convirtiéndose en un instrumento político, por su vinculación con otros textos de ese carácter, como el Libro verde de Aragón.

Determinar una u otra cosa depende, eso sí, de que podamos determinar quién fue el verdadero autor de las cartas. Por lo visto a lo largo de estas páginas, puede quedar totalmente descartado que el autor fuera el arzobispo Juan Martínez Silíceo. Esta acusación la realizó Adolfo de Castro sin aportar prueba alguna, algo que prácticamente todos los autores posteriores han señalado. Tampoco queda claro que las cartas jugaran algún papel en el proceso de aprobación del estatuto de limpieza de la catedral de Toledo. La vinculación con este episodio se debe a que en algunas copias manuscritas, como la contenida en el Libro verde de Aragón conservado en la Biblioteca Colombina, se afirma que las cartas fueron encontradas por el arzobispo Silíceo y utilizadas por él en su empeño por conseguir la confirmación del estatuto por Roma. Sin embargo, esa historia aparece junto a otras leyendas de marcado carácter antijudío, como la de la muerte del príncipe Juan y las razones que llevaron al rey Fernando el Católico a expulsar a los judíos de España. Esta historia merece tanto crédito como la otra del arzobispo Silíceo. Además, en los papeles que han llegado hasta nosotros del proceso de aprobación del estatuto no se encuentra mención alguna a las cartas. Si el arzobispo Silíceo hubiera tenido en su poder la correspondencia, poca duda cabe de que la habría utilizado, y la habría mencionado una y otra vez en sus escritos de defensa del estatuto de limpieza, al igual que hizo repetido uso de otras leyendas antijudías. Si no la utilizó fue, muy probablemente, porque no estaba en su poder, y ni siquiera la conocía.

Por otro lado, algunos autores, como Sicroff y Caro Baroja, han visto una referencia explícita a la correspondencia en la obra de defensa del estatuto de limpieza de sangre de la catedral de Toledo escrita por el obispo Diego de Simancas, publicada en 1575. Sin embargo, esa referencia no existe. El obispo solo se refirió a la existencia de un rumor que consideraba poco créble. Si hubiera conocido las cartas de primera mano, o hubiera sabido de su existencia, habría hablado de ellas, no de un rumor. Aún así, resulta evidente que tiene que existir algún tipo de vinculación entre la correspondencia y esa obra, dada la forma tan semejante

58. Carpenter, D. E.: «Polémicos privilegios: dos versiones de la primera sátira conocida en contra de los conversos», Sefarad, 72 (2), 2012, pp. 295-324; González Rolán, T. y SAQuero, P. (Eds.): De la Sentencia-estatuto de Pero Sarmiento a la Instrucción del relator. Madrid, 2012, pp. 79-91.

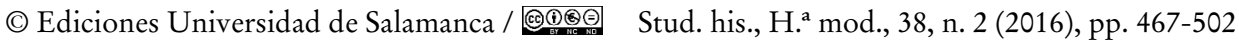


en la que en ambos textos se hace relación de los oficios que los conversos deben ocupar y la finalidad que deben darles. El hecho de que el propio Simancas restara credibilidad al rumor indica que no fue creación suya, y que muy posiblemente corriera por España como otra de las múltiples leyendas antijudías que circularon en la época. Es, por tanto, muy posible que Simancas y el autor de la correspondencia bebieran de la misma fuente, o que el autor de las cartas hubiera conocido la obra de Simancas y se hubiera inspirado en ella.

Esto nos lleva, irremediablemente, a Julián de Medrano. Algunos de los historiadores de la literatura que han tratado este tema, como Beusterien, han considerado que Medrano fue el autor de la correspondencia, y que lo hizo por motivos estrictamente literarios. Escribió un texto satírico que luego fue utilizado por otros con fines bien diferentes. Sin embargo, se sabe demasiado poco de la vida de Medrano como para poder aventurar juicios a este respecto ${ }^{59}$. Es muy posible que, inspirado por Simancas, o por el rumor al que este se refirió, Medrano diera forma definitiva a las cartas. Puede ser también que las plagiara, como hizo con otros muchos textos incluidos en La silva curiosa $^{60}$. Estamos lejos de poder afirmar nada en un sentido o en otro. Sin embargo, la conexión con el Libro verde de Aragón que menciona Beusterien resulta interesante y quizás podría ayudar a explicar muchas cosas. El hecho de que la obra de Medrano se publicara de forma pirata en Zaragoza - con fecha ficticia de 1580-, el que en las cartas en su versión del Libro verde -en la copia de la Biblioteca Colombina- se cambiara el «Chamorra» que firmaba la primera de las cartas en la versión de Medrano por un "Chamorro", precisamente uno de los apellidos mencionados en el Libro, son, indudablemente, indicios de que alguna conexión puede existir. Pero también es verdad que, sin saber en qué fecha exacta se introdujeron las cartas en el Libro verde es muy difícil establecer qué fue primero, si la obra de Medrano o las cartas del Libro.

En cuanto a las copias manuscritas que se han identificado hasta hoy, ninguna de ellas puede datarse de forma precisa. Las fechas que algunas de las copias contienen son irrelevantes, dado el carácter apócrifo de las propias cartas. Quizás la fecha real de alguna de ellas podría avanzarse hasta la década de los 70 , pero no parece muy probable, dada la ausencia total de referencias indirectas. Todo indicaría, pues, que todas las descubiertas hasta hoy son más recientes, de finales del siglo Xvi o más tardías.

59. Vid. Bravo López, F.: «Breve nota biográfica sobre Julián Íñiguez de Medrano, autor de La silva curiosa», LEMIR, 20, 2016, pp. 9-16.

60. Vid. Menéndez y Pelayo, M.: Orígenes de la novela. 4 vols., Madrid, 1905-1915, vol. 2, pp. lxxviii-lxxxi.

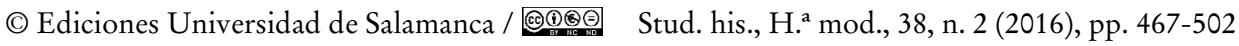


Por lo que respecta a las firmas de las cartas, hemos visto que durante el debate en la Revue des Études Juives se apuntaron muchas posibilidades, pero nada cabe extraer de ello que pueda ayudar a entender mejor el origen y el propósito de la correspondencia, al menos si no se responden antes otra serie de preguntas más importantes. Y eso, entre otras cosas, porque no se sabe en realidad cuáles son las firmas originales. Medrano las firmó con un «Chamorra» y un «Ussusff», pero en la copia manuscrita del Libro verde se firma con un «Chamorro» y un «Uliff»; y en otras copias con «Chamoro» $y$ «Usufu», con «Echar Morro» $y$ «Vsuf», o con «Chamero» $\mathrm{y}$ «Philipo» ${ }^{61}$.

Sobre la historia de la correspondencia en Francia, la aportación más destacada es, sin duda, la de Aeskoly. Después de mucho tiempo afirmándose que la historia de los judíos de Provenza, y de los conversos y sus descendientes, no tenía ninguna relación con la correspondencia, Aeskoly demostró que existió un contexto sociopolítico propicio para que las cartas fueran esgrimidas como prueba de la necesidad de discriminar a los descendientes de conversos de determinados cargos públicos. Se demostraba así que en la Provenza hubo un intento fallido de introducir estatutos de limpieza de sangre en determinadas instituciones, y que ese contexto explicaba el recurso a las cartas españolas, su aparición en determinadas obras manuscritas y en la obra del abate Bouis, así como la transformación de la primera de ellas en la carta de los judíos de Arlés.

Sobre la historia de las cartas en Portugal, varios trabajos han demostrado que fueron esgrimidas en varias ocasiones con el objetivo de legitimar la discriminación de los descendientes de conversos. Sin embargo, no se ha demostrado que tuvieran una gran incidencia, ni que circularan profusamente. Únicamente la obra de Costa Matos de 1623 las reproduce íntegramente, y en las demás obras portuguesas de la época solo se las menciona brevemente. En cuanto a la carta del obispo Andrés de Noronha, que tanta tinta ha hecho correr, muy poco nos dice acerca de la historia de la correspondencia en Portugal, ni de su influencia en la legitimación de los estatutos de limpieza de sangre -a no ser que creamos, punto por punto, lo que el obispo afirmaba-. En realidad, pese a lo que han pretendido algunos autores, el documento nos muestra que, en la década de 1580 las cartas eran aún tenidas por algunos como algo que nadie conocía, y que su existencia podía esgrimirse como si de una gran revelación se tratara. El documento, por

61. Véanse las distintas copias en Yanguas y Miranda, J.: Diccionario de antigüedades del Reino de Navarra. 3 vols., Pamplona, 1840, vol. 2, pp. 119-120; SANGRAdOR Vítores: op. cit., p. 81; S.M.: «Carta de los judíos de España á los de Constantinopla, hallada en el Archivo de Barcelona, sobre obligarles a que sean Christianos", Revista de Archivos, Bibliotecas y Museos, II (16), 1872, pp. 254-255; El libro verde de Aragón, op. cit., p. 210.

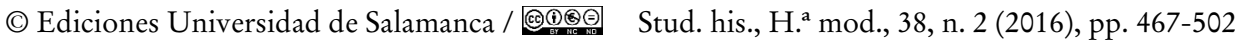


tanto, muestra que, para finales del siglo xvi las cartas aún no habían circulado tanto como hasta hoy se ha creído.

En definitiva, a pesar de los muchos avances que se han realizado hasta hoy, estamos lejos aún de conocer cuál fue el origen real de la correspondencia entre los judíos de España y los de Constantinopla. No sabemos en qué momento nació, ni cuál fue su autor, ni qué motivos le llevaron a idear tan exitosa creación, ni cómo ni por qué razones empezó a circular en un primer momento, aunque sí sabemos por qué posteriormente fue tan utilizada. Sin embargo, existen muchos indicios que indicarían que las cartas son más tardías de lo que en muchas ocasiones se ha afirmado. Aunque es muy posible que existiera una leyenda previa, es probable que la correspondencia que hoy conocemos tuviera su origen en las décadas finales del siglo XvI, y que no se pusiera en circulación de manera importante hasta las primeras del XviI.

\section{Bibliografía}

Acuña, S.: Dissertaciones sobre el órden, que los médicos deben observar en las juntas. Madrid, Librería de Luis Correa, 1746.

Aeskoly, A. Z.: «The Correspondence Between the Jews of Spain and Provence and the Jews of Constantinople, and the History of the Marranos of Provence (en hebreo)», Zion, 4 (1), 1945, pp. 102-139.

Alamín, F.: Impugnación contra el Talmud de los judios, al Coran de Maboma, y contra los hereges. Madrid, Imprenta de Lorenço Francisco Mojados, 1727.

Álvarez Chillida, G.: El antisemitismo en España: la imagen del judio, 1812-2002. Madrid, Marcial Pons, 2002.

Amador de los Ríos, J.: «De los judíos de España. Artículo X y último», Revista Literaria de El Español, 38, 1846, pp. 5-9.

AmAdor de los Ríos, J.: Estudios históricos, políticos y literarios sobre los judios de España, Madrid, Impr. de M. Díaz y Comp., 1848.

Amador de los Ríos, J.: Historia social, política y religiosa de los judíos de España y Portugal. 3 vols., Madrid, Imp. T. Fontanet, 1875.

Amador De los Ríos, R.: «El Libro verde de Aragón», Revista de España, 105, 1885, pp. 547-578.

Amador de los Ríos, R.: «El Libro verde de Aragón», Revista de España, 106, 1885, pp. 249-288, 567-603.

Amran, R.: «Calumnias y falsificación histórica: dos casos de correspondencia apócrifa relacionadas con judíos hispanos durante el medioevo", Cabiers de Linguistique Hispanique Médiévale, 29, 2006, pp. 317-326.

Azevedo, J. L.: História dos cristãos novos portugueses. Lisboa, Teixeira, 1921.

Barrios, M.: «Álbum de recuerdos», ABC. Edición de Sevilla, 15 de enero de 2000.

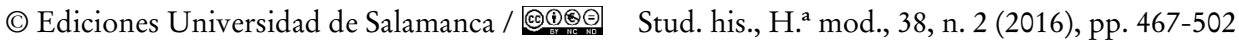



Y LOS DE CONSTANTINOPLA: UNA REVISIÓN CRÍTICA

Beusterien, J.: «The Spanish “Jewish Conspiracy” Letters», The Monographic Review, 22, 2006, pp. 33-45.

Bouis, J.: La royalle couronne des roys d'Arles. Aviñón, Impr. Jaques Bramereau, 1641.

Bravo López, F.: «Breve nota biográfica sobre Julián Íñiguez de Medrano, autor de La silva curiosa», LEMIR, 20, 2016, pp. 9-16.

Brenier, F.: Les juifs et le Talmud. París, Ligue Française Antimaçonnique, 1913.

Bytwerk, R. L.: Julius Streicher. Nueva York, Cooper Square Press, 2001.

Cantera Burgos, F.: «El problema de los criptojudíos al escalar el trono Felipe III», en Homenaje al excmo. Sr. Dr. don Emilio Alarcos García. 2 vols., Valladolid, Universidad de Valladolid, 1967, vol. 2, pp. 633-642.

Caro Baroja, J.: Los judios en la España moderna y contemporánea, I. 4. ${ }^{a}$ ed., Tres Cantos, Istmo, 2000.

Caro Baroja, J.: Los judios en la España moderna y contemporánea, II. 4. a ed., Tres Cantos, Istmo, 2005.

Carpenter, D. E.: «Polémicos privilegios: dos versiones de la primera sátira conocida en contra de los conversos», Sefarad, 72 (2), 2012, pp. 295-324.

CARrasco, R.: «La nueva Jerusalén y la memoria judeoconversa (siglos XVI-XVII)», en CARrasco, R. et al. (Eds.): La Inquisición y la sociedad Española. Valencia, Real Sociedad Económica de Amigos del País, 1996, pp. 9-30.

Castro, A.: Historia de los judios en España. Cádiz, Imp. Revista Médica, 1847.

Cohn, N.: El mito de la conspiración judía mundial. Madrid, Alianza editorial, 1995.

Contreras, A.: Mayor fiscal contra judios. Madrid, Gabriel del Barrio, 1736.

Copin-Albancelli, P.: La conjuration juive contre le monde chrétien. París y Lyon, La Renaissance Française y Librairie Emmanuel Vitte, 1909.

Costa Matos, V.: Breve discurso contra a heretica perfidia do judaismo. Lisboa, Pedro Craesbeeck imp., 1623.

Chabauty, E.-A.: Les Juifs, nos maîtres! París, Société Générale de Librairie Catholique, 1882.

Darmesteter, A.: «Lettres des juifs d'Arles et de Constantinople», Revue des Études Juives, 1, 1880, pp. 119-123.

Desportes, H.: Le mystère du sang chez les juifs de tous les temps. París, Albert Savine, 1890.

Domínguez Ortiz, A.: La clase social de los conversos en Castilla en la Edad Moderna. Madrid, Instituto Balmes de Sociología, CSIC, 1955.

Drumont, É.: La France Juive. 2 vols., París, C. Marpon \& E. Flammarion, 1886.

El libro verde de Aragón. Edición de Monique Combescure, Zaragoza, Librería Certeza, 2003.

Estatuto de la Sancta Iglesia de Toledo. Biblioteca Nacional de España, ms. 10608.

Fernández de Otero, A.: Tractatus de officialibus reipublicae. Ginebra, Apud Fratres de Tournes, 1750 [1. ${ }^{\mathrm{a}}$ ed. Lyon, 1682].

Gómez Moreno, Á.: España y la Italia de los humanistas. Madrid, Gredos, 1994.

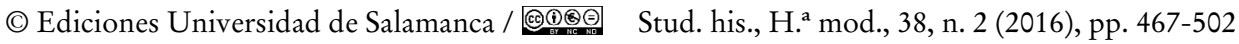


González Rolán, T. y Saquero, P. (Eds.): De la Sentencia-estatuto de Pero Sarmiento a la Instrucción del relator. Madrid, Aben Ezra, 2012.

Goodman, D.: Poder y penuria: gobierno, tecnología y sociedad en la España de Felipe II. Madrid, Alianza editorial, 1990.

GRAETZ, H.: «But réel de la correspondance échangée vers la fin du Xve siécle entre les juifs espagnols et provençaux et les juifs de Constantinople», Revue des Études Juives, 19, 1889, pp. 106-114.

Hoyos y de la Torre, I.: Los judios españoles en el Imperio Austríaco y en los Balkanes. Madrid, Est. Tip. de Fortanet, 1904.

«La letro di jusiou d'Arle», Armana Prouvençau, 1880, pp. 61-62.

LAmbelin, R.: Le péril juif: l'imperialisme d'Israël. París, Grasset, 1924.

LEA, H. C.: A History of the Inquisition of Spain. 4 vols., Londres, MacMillan, 1906-1907.

Loeb, I.: «La correspondance des Juifs d'Espagne», Revue des Études Juives, 15, 1887, pp. 262-276.

López Martínez, N.: Los judaizantes castellanos y la Inquisición en tiempo de Isabel la Católica. Burgos, Seminario Metropolitano de Burgos, 1954.

Llorente, J. A.: Anales de la Inquisición española. 2 vols., Madrid, Imp. Ibarra, 1812-1813.

Medrano, J.: La silva curiosa de Julián de Medrano. Estudio y edición crítica de Mercedes Alcalá Galán, Nueva York, Peter Lang, 1998.

Mendes dos Remédios, J.: Os judeus em Portugal, I. Coimbra, Amado, 1895.

Méndez Bejarano, M.: Histoire de la juiverie de Séville. Madrid, Editorial Ibero-Africano-Americana, 1922.

Menéndez y Pelayo, M.: Orígenes de la novela. 4 vols., Madrid, Bailly-Baillière e Hijos, 1905-1915.

Meurin, L.: La franc-maçonnerie, synagogue de Satan. París, Victor Retaux et Fils, 1893.

Montero de Espinosa, J. M.: Relación histórica de la judería de Sevilla. Sevilla, Imp. de Carrera y Co., 1820.

Morel-Fatio, A.: «Les lettres des Juifs d'Arles et de Constantinople: lettre a M. Arsène Darmesteter», Revue des Études Juives, 1, 1880, pp. 301-304.

Netanyahu, B.: Los orígenes de la Inquisición en la España del siglo XV. Barcelona, Crítica, 1999.

OchoA, E.: Catálogo razonado de los manuscritos españoles existentes en la Biblioteca Real de París. París, Imp. Real, 1844.

Parello, V.: «De l'antisémitisme théologique médiéval à l'antisémitisme économique: le cas de l'allégation du bachelier Pedro Ortiz (1546)», Mélanges de la Casa de Velázquez, 30 (2), 1994, pp. 7-28.

Parello, V.: Les judéo-convers: Tolède, xve-Xvie siècles: de l'exclusion à l'intégration. París, Harmattan, 1999.

Pérez OchoA, Í.: «El "Padrón” y la "Manta” de Tudela: documentación acerca de los judeoconversos y la Inquisición en Navarra», Sefarad, 74 (2), 2014, pp. 389-426.

(C) Ediciones Universidad de Salamanca / ®@ Stud. his., H. ${ }^{a}$ mod., 38, n. 2 (2016), pp. 467-502 

Y LOS DE CONSTANTINOPLA: UNA REVISIÓN CRÍTICA

Porreño, B.: Defensa de el estatuto de limpieza, que fundo en la sancta Iglesia de Toledo el Cardenal, y Arçobispo Don Juan Martínez Silíceo. Biblioteca Nacional de España, ms. 5910.

The Protocols of the Meetings of the Learned Elders of Zion., s. 1., s. n., 1934.

Quero, F.: Juan Martínez Siliceo (1486?-1557) et la spiritualité de l'Espagne pré-tridentine. París, Honoré Champion, 2014.

Quevedo, F.: Execración contra los judios, edición de Fernando Cabo y Santiago Fernández. Barcelona, Crítica, 1996.

Roque-Ferrier, A.: «Bibliographie. Armana prouvençau», Revue des Langues Romanes, 3. ${ }^{\text {a }}$ serie, tomo II, 1879, pp. 301-304.

Rотн, N.: Conversos, Inquisition, and the Expulsion of the Jews from Spain. Madison, The University of Wisconsin Press, 2002.

S.M.: «Carta de los judíos de España á los de Constantinopla, hallada en el Archivo de Barcelona, sobre obligarles a que sean Christianos», Revista de Archivos, Bibliotecas y Museos, II (16), 1872, pp. 254-255.

SAngrador Vítores, M.: Historia de la muy noble y leal ciudad de Valladolid. 2 vols., Valladolid, Imp. de D.M. Aparicio, 1851-1854.

Schwartz-Bostunitsch, G.: Jüdischer Imperialismus. Leipzig, T. Fritsch, 1937.

Serrano y Sanz, M.: Orígenes de la dominación española en América. Estudios Históricos. Tomo Primero. Madrid, Casa Editorial Bailly-Bailliere, 1918.

Sicroff, A.: Los estatutos de limpieza de sangre: controversias entre los siglos XV y XVII. Madrid, Taurus, 1985.

Simancas, D.: Defensio statuti toletani. Amberes, Christophori Plantini, 1575.

Simancas, D.: «La vida y cosas notables del señor obispo de Zamora don Diego de Simancas», en Serrano y Sanz, M. (Ed.): Autobiografías y memorias. Madrid, Baylly-Bailliére, 1905.

SoYer, F.: Popularizing Anti-Semitism in Early Modern Spain and its Empire: Francisco de Torrejoncillo and the Centinela contra judios (1674). Leiden, Brill, 2014, https:// doi.org/10.1163/9789004268876.

Soyer, F.: «The Anti-Semitic Conspiracy Theory in Sixteenth-Century Spain and Portugal and the Origins of the Carta de los judios de Constantinopla: New Evidence», Sefarad, 74 (2), 2014, pp. 369-388, https://doi.org/10.3989/sefarad.014.010.

Torrejoncillo, F.: Centinela contra judios. Madrid, Joseph Fernández de Buendía, 1676.

Villar Maldonado, I.: Sylva responsorum iuris. Madrid, Praelo \& expensis Ludouici Sanchez, Typ., 1614.

Yanguas y Miranda, J.: Diccionario de antigüedades del Reino de Navarra. 3 vols., Pamplona, Imp. de Francisco Erasun, 1840.

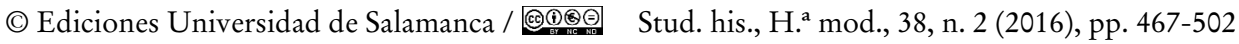

